\title{
Microbial-metazoan reefs of the terminal Proterozoic Nama Group (c. 550-543 Ma), Namibia
}

\author{
J. GROTZINGER*, E. W. ADAMS \& S. SCHRÖDER
}

Department of Earth, Atmospheric and Planetary Sciences, Massachusetts Institute of Technology, Cambridge, MA 02139, USA

(Received 6 April 2004; accepted 31 March 2005)

\begin{abstract}
Thrombolite and stromatolite reefs occur at several stratigraphic levels within the terminal Proterozoic Nama Group (c. 550-543 Ma) of central and southern Namibia. The reefs form integral parts of several carbonate platforms within the Nama Group, including the Kuibis platform of the northern Nama Basin (Zaris subbasin), and Huns platform (Witputs subbasin) of the southern Nama Basin. The reefs are composed of both thrombolites and stromatolites that form laterally continuous biostromes, isolated patch reefs, and isolated pinnacle reefs ranging in scale from a metre to several kilometres in width. In the majority of cases, the reefs occur stratigraphically as an integral facies within the transgressive systems tracts of sequences making up the Kuibis and Huns platforms. This suggests that a regime of increasing accommodation was required to form well-developed reefs, though reefs also occur sporadically in highstand systems tract settings. Within a given transgressive systems tract, a regime of increasing accommodation through time favours the transition from sheet-like biostromal geometries to more isolated patch and pinnacle biohermal geometries. Similarly, increasing accommodation in space, such as a transect down depositional dip, shows a similar transition from more sheet-like geometries in updip positions to more isolated geometries in downdip positions. Reefal facies consist of thrombolitic domes, columns and mounds with well-developed internal clotted textures, in addition to stromatolitic domes, columns and mounds, with crudely to moderately well-developed internal lamination. Stromatolites are better developed in conditions of relatively low accommodation, and updip locations, under conditions of higher current velocities and greater sediment influx. Thrombolites are better developed in conditions of relatively high accommodation and low sediment influx. Both types of microbialites are intimately associated with the first calcifying metazoan organisms, which may have attached themselves to the sediment surface or otherwise lived within sheltered depressions within the rough topography created by ecologically complex mats. The appearance of thrombolitic textures during terminal Proterozoic time is consistent with colonization of cyanobacterial mats by higher algae and metazoans, which would have been an important process in generating clotted textures. Fabrics in the Nama thrombolites are well preserved and show evidence of thrombolitic mesoclots being overgrown by fibrous marine carbonate, interpreted as former aragonite. This was followed by emplacement of geopetal micrite fills, and precipitation of dolomite as an isopachous rim cement, followed by occlusion of remaining porosity by blocky calcite spar.
\end{abstract}

Keywords: carbonate, reef, Ediacaran, thrombolite, Proterozoic.

\section{Introduction}

Investigations of ancient reefs provide a unique and effective method for assessing the biotic, chemical and physical forces operating on biological evolution and sediment production on ancient carbonate platforms. Patterns deduced from their long-term development help document the evolution of carbonate-producing organisms, secular changes in the composition of the ocean and atmosphere, the succession of tectonic and subsidence regimes, the mechanisms and magnitudes of eustasy, fluctuations in climate, and the physical conditions in which sedimentation took place. For Phanerozoic reefs, description of facies, formulation

\footnotetext{
* Author for correspondence: grotz@mit.edu
}

of models and analysis of variability have been highly successful in fulfilling these objectives (Heckel, 1974; Wilson, 1975; James, 1983; Tucker \& Wright, 1990).

Increasingly, Proterozoic reefs are being considered within the context of the entire depositional system, and using modern approaches and comprehensive analogues (Grotzinger \& James, 2000). The general growth, spatial arrangement of facies and evolution of many Proterozoic reefs are surprisingly similar to younger platforms, although the individual facies are in most cases quite different (Grotzinger, 1989, 1994). Today, the most conspicuous gap in our understanding of the first-order, long-term evolution of reefs concerns the transition from the Proterozoic realm of microbial and abiotic carbonates to the Phanerozoic world of metazoan- and metaphyte-dominated 


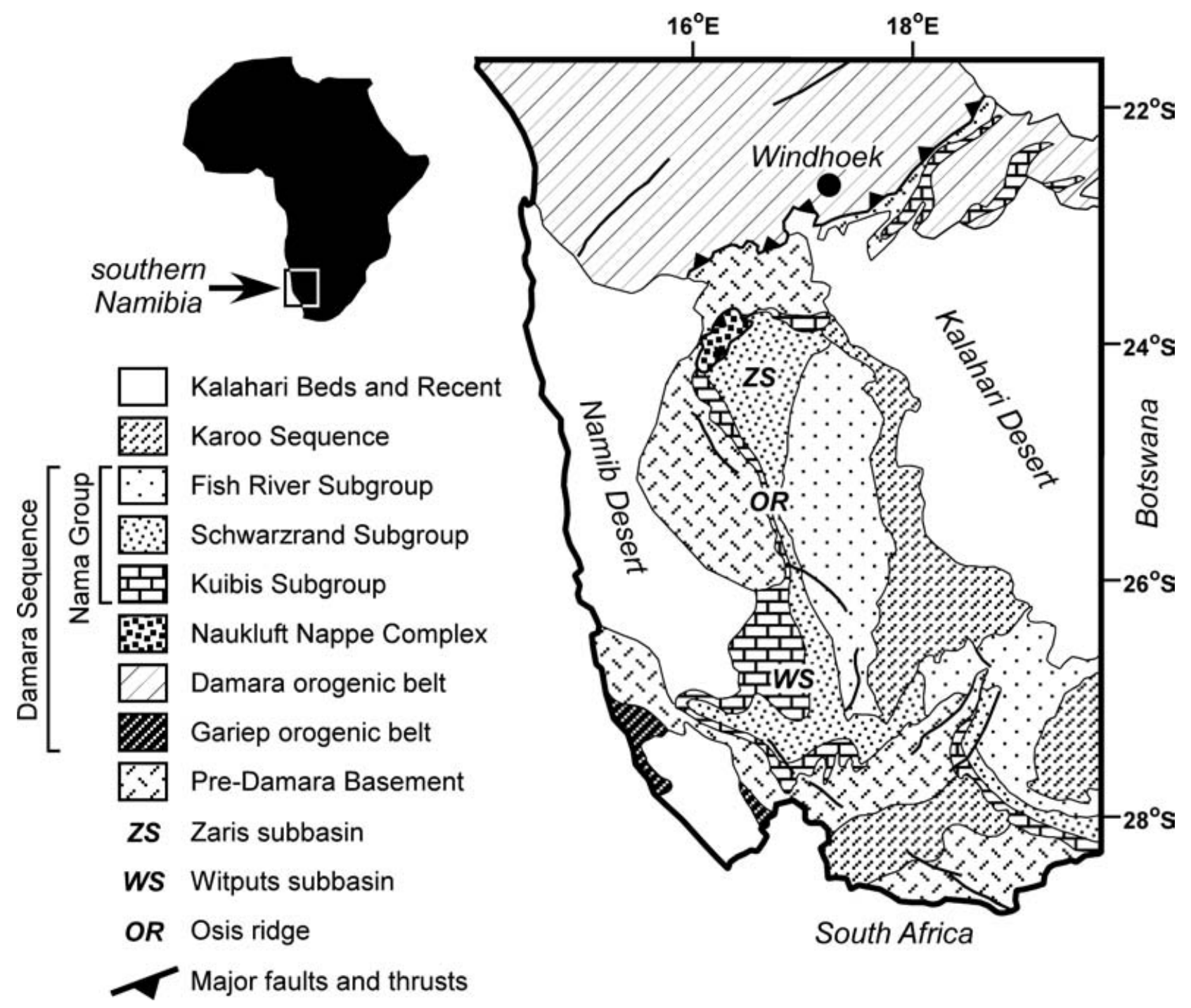

Figure 1. Geological map of southern Namibia showing distribution of major tectonic elements, including the Nama Group.

sediment production. The explosive diversification in shelly invertebrates and burrowing infauna near the Precambrian-Cambrian boundary (Valentine et al. 1991; Sepkoski, 1992; Bowring et al. 1993) resulted in a dramatic change in the fundamental textures of facies and modes of carbonate production (Grotzinger \& James, 2000). A few studies of the earliest Phanerozoic carbonates have focused on the structure and diversity of Lower (but not lowest) Cambrian Archaeocyathidmicrobial reefs (e.g. Riding \& Zhuravlev, 1995), while others have involved studies of upper (but not the uppermost) Proterozoic stromatolite-thrombolite reefs (e.g. Turner, Narbonne \& James, 1993). However, there have been few studies of the youngest Proterozoic reefs where the first well-developed, frame-building thrombolites occur (Grotzinger \& Khetani, 1994) in direct association with the first calcified invertebrates (Germs, 1972a; Grant, 1990; Grotzinger et al. 1995; Grotzinger, Watters \& Knoll, 2000) and calcified metaphytes (Grant, Knoll \& Germs, 1991). Consequently, it is essential to undertake systematic analysis of terminal Proterozoic reefs in order to document properly the first influences of calcified invertebrates and metaphytes on sediment production, platform palaeoecology and facies development.

The research reported here involves a detailed investigation of the sedimentological, stratigraphic, palaeoenvironmental and palaeontological aspects of thrombolite-stromatolite-metazoan reefs developed during terminal Proterozoic time. The reefs described below occur at several stratigraphic levels within the terminal Proterozoic Nama Group of central and southern Namibia.

\section{Geological setting of the Nama Basin}

The geology of southern Namibia, including the distribution of the Nama Group, is shown in Figure 1. The Nama Group has been interpreted as a foreland basin fill (Germs, 1983; Gresse \& Germs, 1993) 
related to convergence along the western and northern margins of the Kalahari craton and overthrusting in the Damara orogen (Miller, 1983). Emplacement of the greenschist grade Naukluft nappe complex, which in part involves Nama stratigraphy, occurred between 570 and $560 \mathrm{Ma}$ (Horstmann et al. 1990), although flexural subsidence in the Nama foreland basin has been calibrated to continue up to about $543 \mathrm{Ma}$, when the basin was filled with fluvial molasse related to final unroofing of the Damara hinterland (J. Grotzinger, unpub. observations).

The general stratigraphy of the Nama Group has been outlined by Martin (1965) and in a series of papers by Germs $(1972 b, 1974,1983)$. Regional isopachs and facies distributions define two subbasins; the Witputs subbasin, located in southern Namibia, deepens toward the Gariep orogenic belt, whereas the more northerly Zaris subbasin deepens northward toward the Damara orogenic belt. The Osis Arch represents a site of depositional thinning of all Nama units and separates the two subbasins (see Fig. 1). The Nama Group generally consists of a number of marine shelf siliciclastic and carbonate sequences (Kuibis and Schwarzrand subgroups) overlain by alluvial to shallow-marine molasse (Fish River Subgroup) that represents unroofing of the Damara hinterland. Near the subbasin axes, thicknesses are on the order of 2-3 km, thinning to less than $1 \mathrm{~km}$ farther onto the craton toward the Osis Arch (Germs, 1974, 1983). Geochronological constraints are provided by $\mathrm{U}-\mathrm{Pb}$ zircon ages on several units within the Nama Group (Grotzinger et al. 1995). An ash bed within the northern Nama basin yields an age of 548.9 Ma for the middle Kuibis Subgroup (Grotzinger et al. 1995). In southern exposures of the Nama, the overlying Schwarzrand Subgroup contains ash beds which yield, in ascending order, ages of $545.1 \mathrm{Ma}, 543.3 \mathrm{Ma}$ and $539.4 \mathrm{Ma}$ (Grotzinger et al. 1995). The Precambrian-Cambrian boundary in Namibia is bracketed by the $543.3 \mathrm{Ma}$ and 539.4 Ma ages, although this also includes a significant unconformity; on a global basis the PrecambrianCambrian boundary is currently regarded to be on the order of 543-542 Ma (Grotzinger et al. 1995; Amthor et al. 2003).

\section{Stratigraphic setting of Nama reefs}

Microbial-metazoan reefs in the Nama Group are best developed in the Kuibis Subgroup of the northern, Zaris subbasin, and on the Huns platform of the southern, Witputs subbasin (Fig. 2). The reefs discussed here are all constrained to be younger than $548.8 \pm 1 \mathrm{Ma}$ and older than $545.5 \pm 1 \mathrm{Ma}$, based on direct dating of reef-bearing strata (Grotzinger et al. 1995). The age of the Kuibis platform is directly constrained by a U$\mathrm{Pb}$ zircon date of $548.8 \pm 1 \mathrm{Ma}$, though its base is probably on the order of $550 \mathrm{Ma}$, and its top somewhat younger, at about $547 \mathrm{Ma}$. The stratigraphically higher
Huns platform is younger, and is constrained to be on the order of $546 \mathrm{Ma}$, based on a U-Pb age date of $545.5 \pm 1 \mathrm{Ma}$ in strata that occur directly above the top of the Huns platform, and on the basis of regional correlations (Grotzinger et al. 1995).

\section{3.a. Huns platform}

The Huns Member consists of a thick section $(0$ $500 \mathrm{~m}$ ) of platform carbonates in the middle of the Nama Group, in the Witputs subbasin of southern Namibia (Fig. 2). First designated the 'Schwarzkalk Limestone' by Martin (1965), it was later described in more detail by Germs $(1972 b, 1974,1983)$, who recognized the presence of pinnacle reefs (Fig. 3) on the Swartkloofberg farm. Subsequent work (Grotzinger \& Khetani, 1994; Saylor \& Grotzinger, 1996; Saylor et al . 1998) showed that these reefs are associated with drowning of the platform, prior to deposition of the Feldschuhhorn shale. The Huns is interpreted as a broad carbonate ramp, divisible into three palaeogeographic zones that include inner ramp, ramp crest and a rampto-basin transition exposed mostly in an east-to-west transect (Saylor, 2003). The present-day level of erosion has removed the most updip components of the Huns platform west of the Fish River, and it is truncated beneath the sub-Nomstas unconformity between Gogeb and Helmeringshausen. It is well exposed from the Huns Mountains west to the Swartpunt and Swartkloofberg farms.

Saylor and co-workers (Saylor, Grotzinger \& Germs, 1995; Saylor \& Grotzinger, 1996, Saylor et al. 1998; Saylor, 2003) have described the regional facies variations which pass from shallow-water, updip facies in northern and eastern localities to deeper-water, downdip facies in southwestern localities, close to the Gariep thrust front. Detailed mapping has shown the presence of several thrust structures which telescope the platform in the Swartpunt and Swartkloofberg farms, resulting in the tectonic emplacement of deeper-water facies over shallow-water facies (Fig. 3b; Saylor \& Grotzinger, 1996).

Small patch reefs occur at several stratigraphic levels in the Huns platform, particularly associated with flooding surfaces in metre-scale cycles which compose much of the platform (Saylor, 2003). However, the only pinnacle reefs discovered so far occur at the top of the platform, above a sequence boundary and within the overlying flooding interval that defines the TST of the overlying sequence (Grotzinger et al. 1995; Saylor \& Grotzinger, 1996; Saylor, 2003). These reefs are 50 $70 \mathrm{~m}$ wide at their base and up to $50 \mathrm{~m}$ high (Fig. 3a, b); they are blanketed by enclosing shales, deposited at or below wave base (Fig. 3b).

\section{3.b. Kuibis platform}

The Kuibis Subgroup is the basal unit of the Nama Group. It is regionally widespread, consisting of a thin, 


\section{Zaris subbasin}

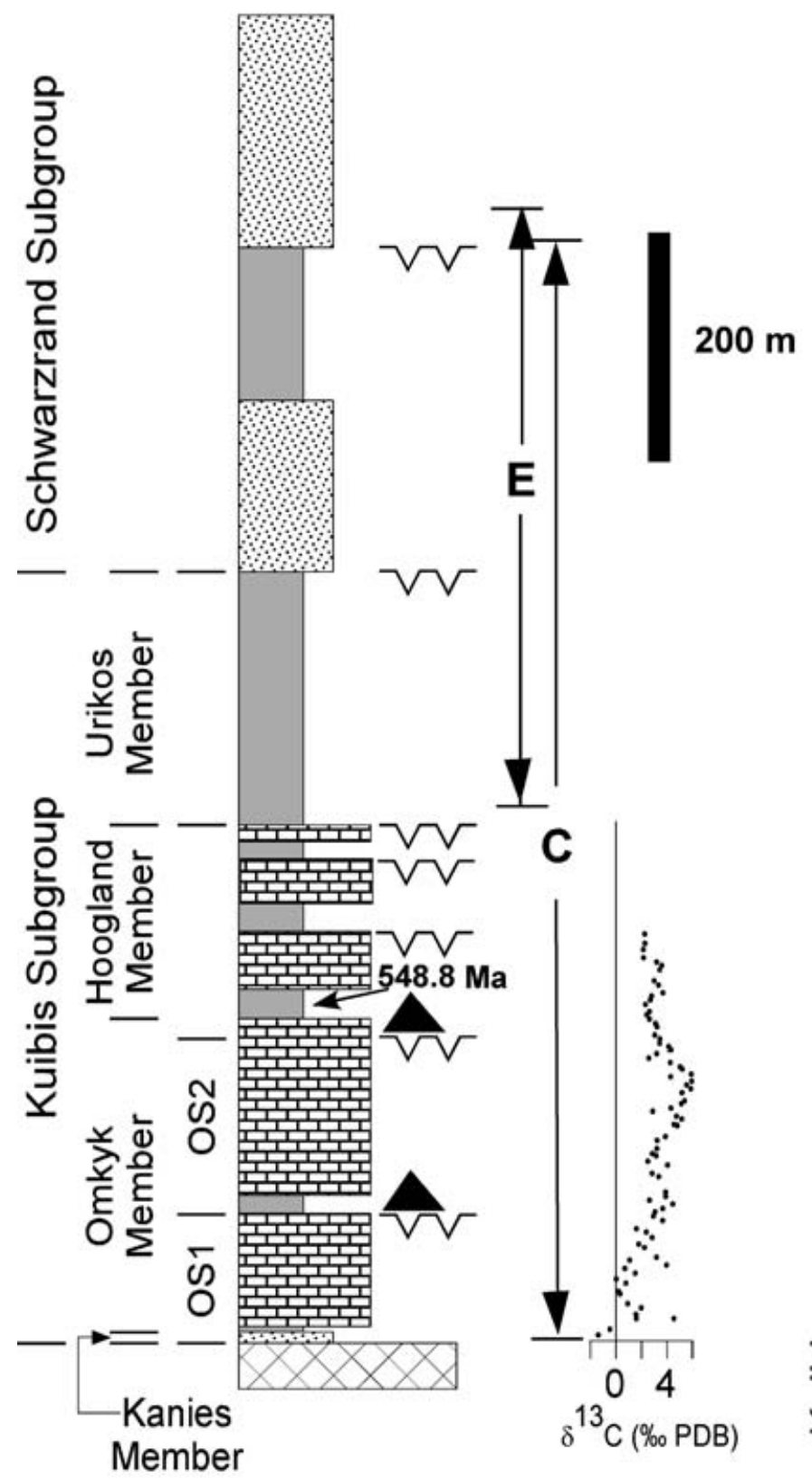

\section{Witputs subbasin}

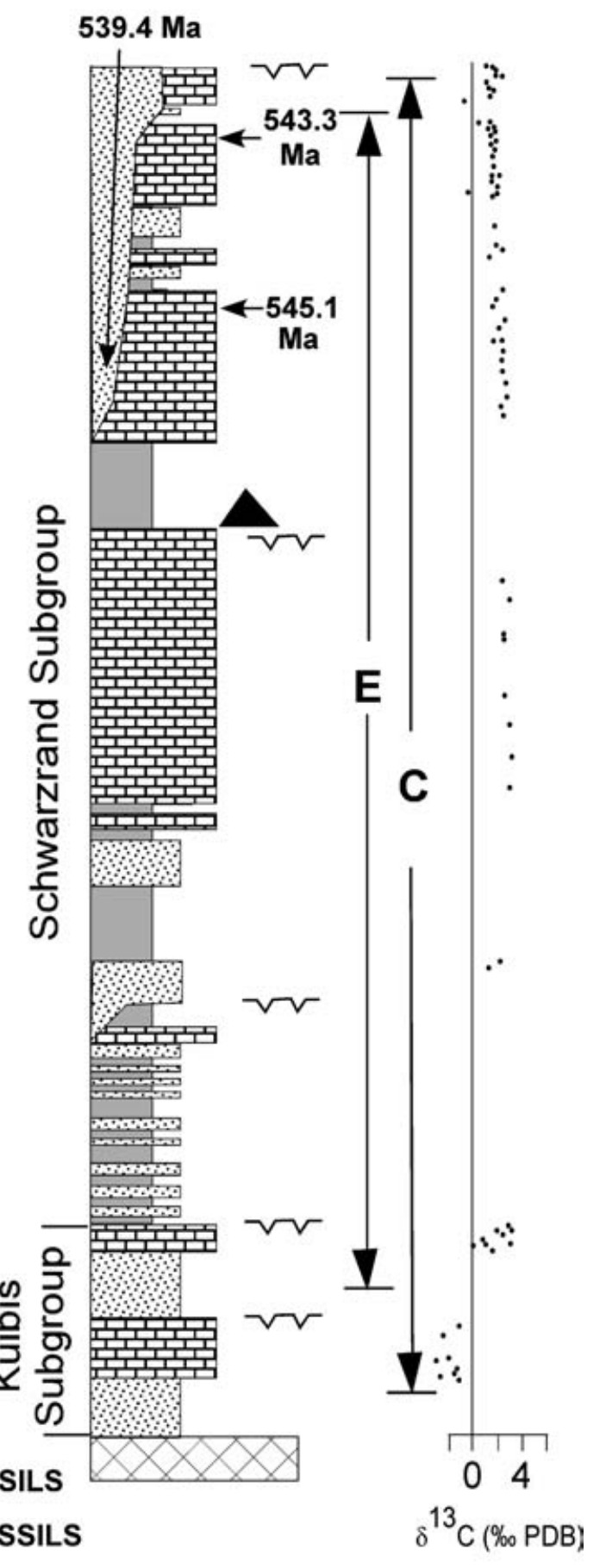

$\delta^{13} \mathrm{C}(\% \mathrm{PDB})$

SHALE

C RANGE OF CALCIFIED FOSSILS

E RANGE OF EDIACARAN FOSSILS

\section{臣 LIMESTONE}

\section{SEQUENCE BOUNDARY}

\section{BASEMENT}

\section{THROMBOLITE/STROMATOLITE BUILDUP}

Figure 2. Generalized stratigraphy of Nama Group for the Zaris subbasin (north) and Witputs subbasin (south), showing major lithostratigraphic, chemostratigraphic, biostratigraphic and sequence stratigraphic attributes. Note position of thrombolite-stromatolite reef complexes above sequence boundaries.

basal, transgressive sandstone that grades upward into a major carbonate platform ranging in thickness from 150 to $500 \mathrm{~m}$. Proximal facies are mostly limestone, whereas deepwater facies are mixed with shales and fine sandstones. Outcrops of the Kuibis Subgroup extend from the Gobabis area of 

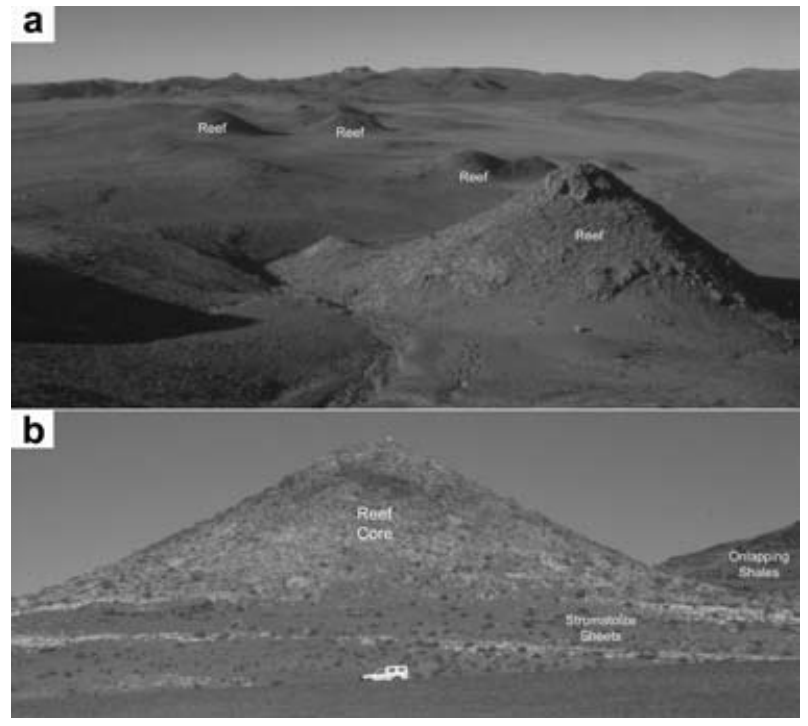

Figure 3. Thrombolite-stromatolite pinnacle reefs at top of Huns platform, Witputs subbasin, southern Namibia. Reefs are formed of a core of coalesced thrombolite mounds, overgrown by a stromatolitic mantle. (a) Overview of multiple pinnacle reefs formed at top of Huns platform. Reefs have been exhumed by erosion of overlying shales. The large reef in the foreground has a basal width of about $60 \mathrm{~m}$. (b) Crosssection of representative pinnacle reef showing foundation of stromatolite sheet facies, and remnants of overlying shales which have been eroded to expose reefs. A sequence boundary occurs between the stromatolite sheet facies and pinnacle reef facies, thus, the pinnacle reefs were formed during a time of increasing accommodation space within a transgressive systems tract.

west-central Namibia to the Naukluft Mountains of east-central Namibia, continuing southward along the escarpment to southern Namibia and into northeast South Africa (Germs, 1972b, 1974; Gresse \& Germs, 1993).

In the Zaris subbasin (Figs 1, 4), the Kuibis Subgroup forms a well-developed carbonate ramp that thickens from the Osis arch northward to the Naukluft Mountains (O. Smith, unpub. M.Sc. thesis, Massachusetts Inst. Tech., 1999). This change in thickness is accompanied by a gradation from shallowwater facies in the south to deeper-water, basinal facies near the Naukluft Mountains. The stratigraphy of the Kuibis Subgroup was first outlined by Germs (1972b, 1974, 1983), who subdivided the carbonate ramp into four members (see Fig. 4b), some of which correspond to stratigraphic sequences (Grotzinger et al. 1995; Saylor, Grotzinger \& Germs, 1995; Saylor et al. 1998; O. Smith, unpub. M.Sc. thesis, Massachusetts Inst. Tech., 1999). In many cases, however, the surfaces defining the member boundaries correspond to flooding events rather than sequence boundaries (O. Smith, unpub. M.Sc. thesis, Massachusetts Inst. Tech., 1999). The regional sequence stratigraphy was established by Saylor, Grotzinger \& Germs (1995) and Saylor et al. (1998), and the regional chemostratigraphy by Kaufman et al. (1991), Saylor, Grotzinger \& Germs (1995) and Saylor et al. (1998). Smith (O. Smith, unpub. M.Sc. thesis, Massachusetts Inst. Tech., 1999) conducted a detailed study of the Kuibis Subgroup in the Zaris subbasin, resulting in a highresolution litho-, sequence- and chemostratigraphic model.

Microbial-metazoan reefs are most abundant in the Omkyk Member. The Omkyk Member of the Kuibis Subgroup corresponds to two stratigraphic sequences (Figs 4b, 5). Along the entire ramp profile, Omkyk Sequence $1(\mathrm{OS} 1)$ is represented by shelf grainstones (Fig. 5). In updip positions of the ramp profile, Omkyk Sequence 2 (OS2) represents a shoaling-upward ramp sequence within which microbial buildups developed at several stratigraphic levels (Fig. 5) (Grotzinger, 2000; Grotzinger,Watters \& Knoll, 2000). Approximately $50 \mathrm{~km}$ downdip, OS2 is represented by a microbialdominated, isolated carbonate platform interfingering with surrounding outer-ramp and basinal shale (Fig. 5; Grotzinger, 2000; Adams et al. 2004).

\section{Sequence stratigraphic framework}

Nama Group reefs show a distinct relationship between their sequence stratigraphic setting, overall geometry (bioherm v. biostrome), and internal composition of the microbial fabric (thrombolite v. stromatolite) (Fig. 5). Detailed mapping of sequences (O. Smith, unpub. M.Sc. thesis, Massachusetts Inst. Tech., 1999; S. DiBenedetto, unpub. M.Sc. thesis, Massachusetts Inst. Tech., 2002; DiBenedetto \& Grotzinger, 2005, this issue) shows that the reefs described here were all nucleated within the transgressive systems tract (TST) to early highstand systems tract (HST) (Fig. 5). This implies that the most favourable conditions for reef growth occurred during times of increased accommodation and lowered carbonate sediment flux on the platform.

A laterally extensive thrombolitic biostrome occupies a position consistent with an interval of increasing accommodation, immediately above the sequence boundary at the top of Omkyk Sequence 2 (Fig. 6). The geometry of this biostrome changes along the ramp profile; in updip positions it is developed as a continuous sheet (within the Zebra River farm), however, it breaks up into patch-reef bioherms toward and within the Donkergange Farm (Fig. 6b, c; Grotzinger, 2000). The transition from continuous biostrome to discontinuous patch reefs is best exposed within the Zebra River valley, west of the property line between Donkergange and Zebra River farms.

On a larger scale, the same pattern is observed. Updip a layer-cake stratigraphy is observed, whereas $50 \mathrm{~km}$ downdip an isolated carbonate platform is developed (Figs 4, 5). 
a

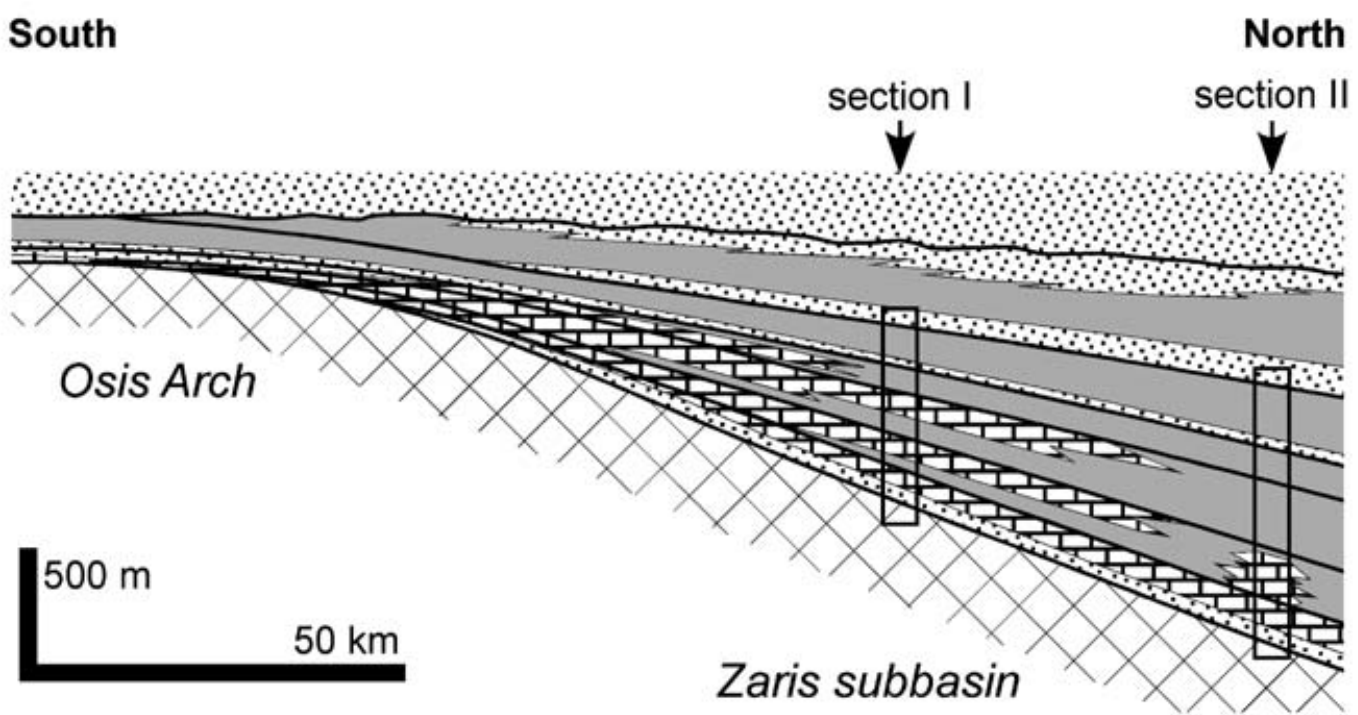

b

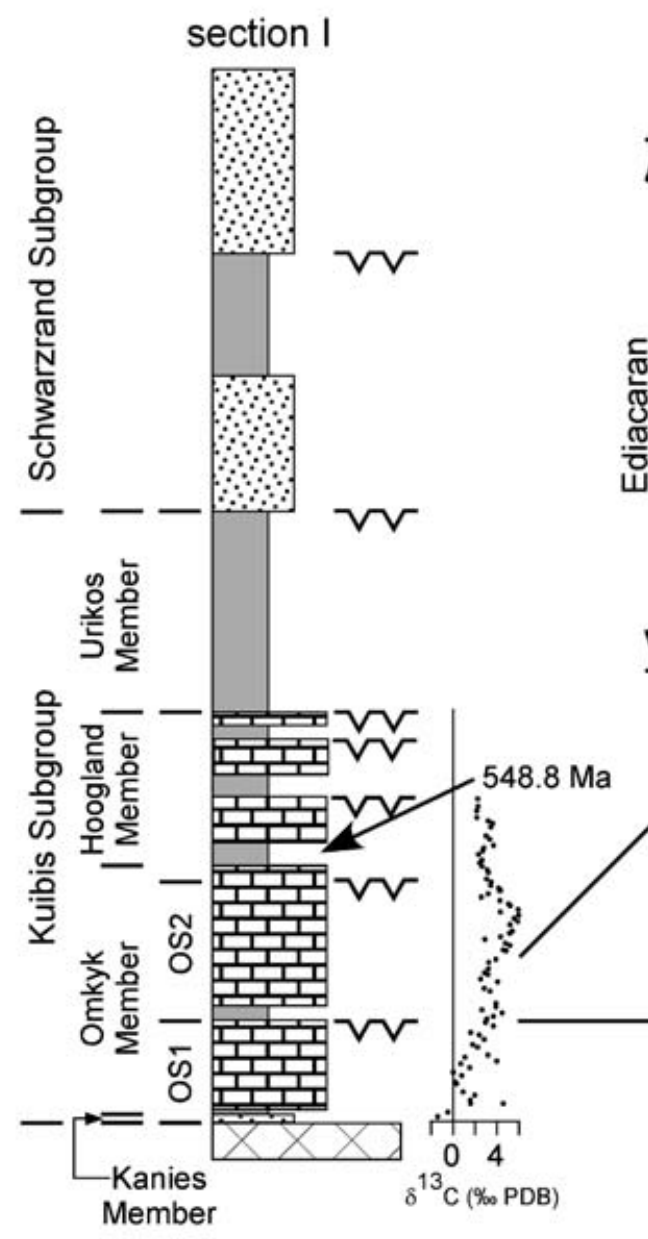

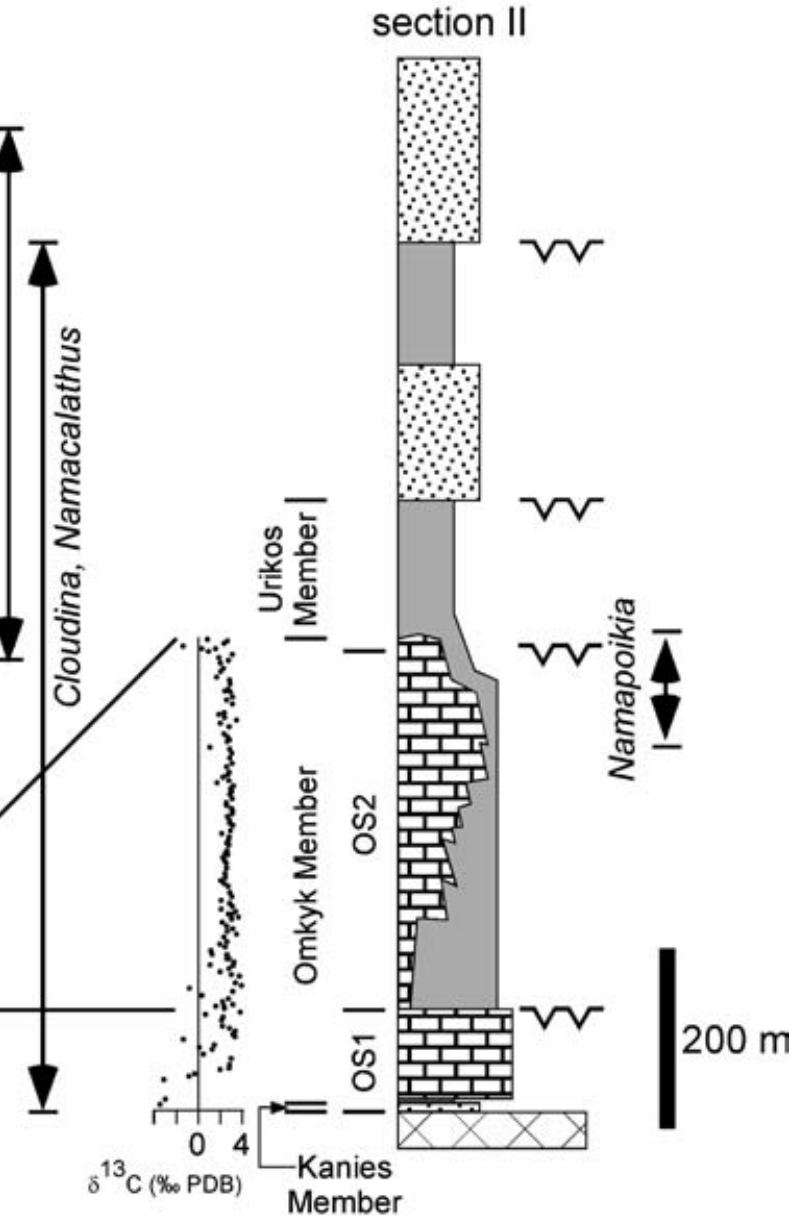

\section{Sandstone \\ Shale and limestone

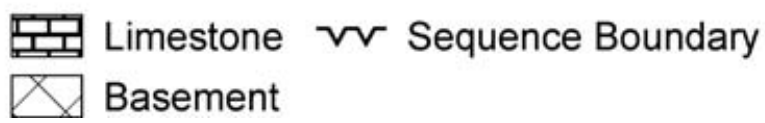

Figure 4. Geological and stratigraphic setting of the lower Nama Group. (a) Schematic south-to-north cross-section across the Zaris subbasin. Note section locations. Modified after Germs (1983). (b) Generalized stratigraphy of Kuibis Subgroup and overlying Schwarzrand Subgroup. An ash bed in the middle Kuibis Subgroup yielded an age of $548.8 \pm 1$ Ma (Grotzinger et al. 1995). Modified after Smith (O. Smith, unpub. M.Sc. thesis, Massachusetts Inst. Tech., 1999). 


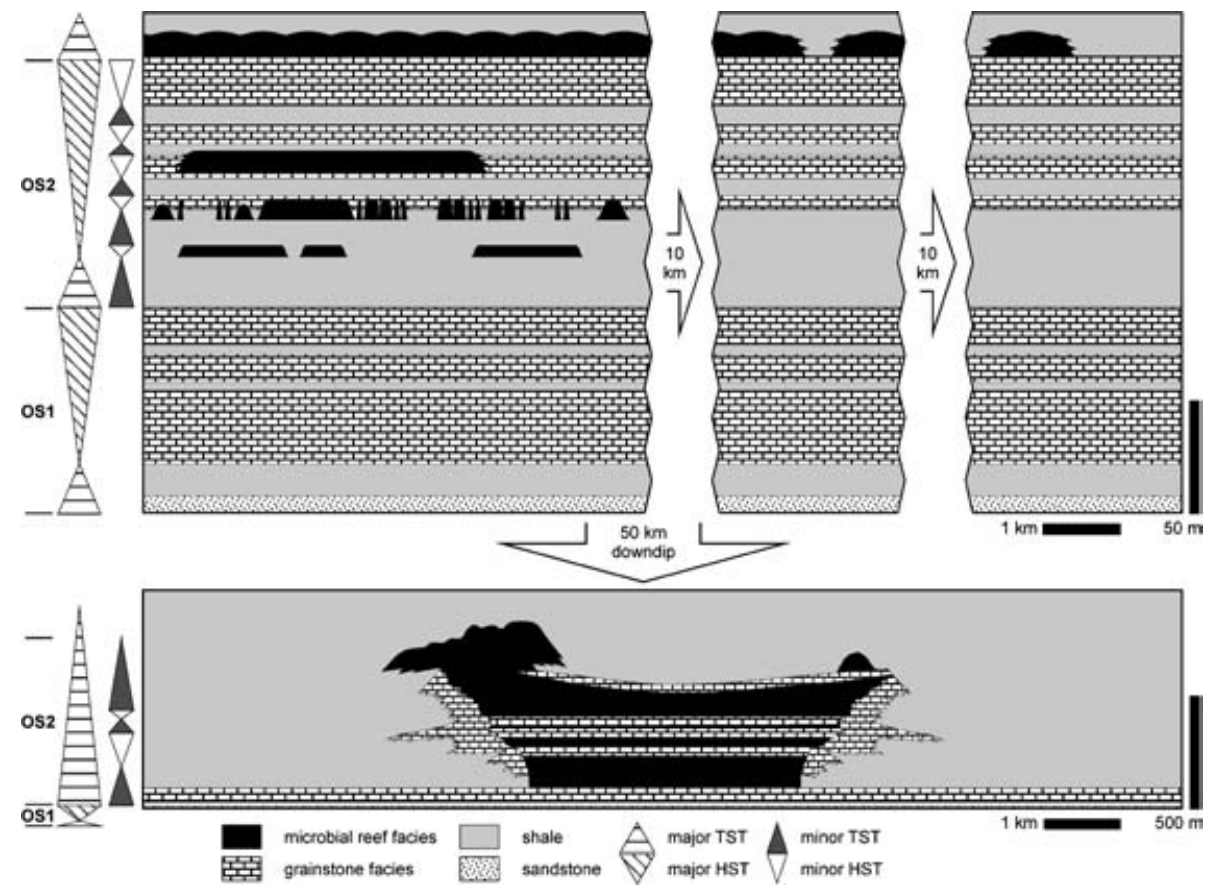

Figure 5. Schematic sequence-stratigraphic framework for thrombolite-stromatolite reefs of the Omkyk Member. Updip, ramp carbonates of the Omkyk Member form two coarsening-upwards shoaling sequences (OS1 and OS2). Intervals dominated by grainstone facies have sheet-like geometries because they accumulated during times of decreasing accommodation. The geometry of microbial reefs varies according to the sequence-stratigraphic setting, that is, bioherm versus biostrome geometry. Downdip, an isolated carbonate platform developed in the vicinity of the Driedoornvlakte farm.

\section{4.a. Bioherms}

Both in updip (e.g. Zebra River Farm) and downdip locations (e.g. Driedoornvlakte Farm), bioherms tend to occur in TST to early HST settings. For example, within a transgressive systems tract, bioherms developed in association with heterolithic fine-grained facies (Fig. 7). In contrast, when accommodation space decreased, such as during the transition to the early HST, the bioherms became associated with grainstones. During the late HST, grainstone deposition covered the microbial reefs, suggesting that the increased carbonate sediment flux on the ramp smothered and terminated reef growth. Internal reef fabrics are dominated by thrombolite domes and columns. These are commonly coalesced and complexly stacked to form larger composite mounds. Domal and columnar thrombolites pass into more stromatolitic fabrics around their margins (Figs 9c, 10a).

The relationship between reef growth and accommodation changes also is illustrated by large pinnacle reefs developing during the last stage of the Driedoornvlakte buildup (Fig. 8; Adams et al. 2004). The Driedoornvlakte buildup evolved during a progressive increase in accommodation over the duration of platform growth, as shown by the shift from a relatively flat upper surface to a platform with a bucket-shaped geometry and elevated margins. Pinnacle reef growth was initiated on this antecedent topography generated by the elevated margins. The pinnacle reef complex reached a total thickness of $250 \mathrm{~m}$ (Adams et al. 2004).
The reef starts with small $(1-5 \mathrm{~m}$ in diameter, $1-$ $2 \mathrm{~m}$ in height) individual thrombolite mounds that also contain less than $20 \%$ small stromatolites. Upsection, the mounds gradually increase in size forming composite structures that reach diameters up to 10 $20 \mathrm{~m}$ and heights up to $5 \mathrm{~m}$. Stromatolites are less abundant in these composite mounds and occur mostly as thin overgrowths on domes and mounds. At its very top, the pinnacle reef breaks up into a set of large isolated thrombolite mounds flanked by shales of the Urikos Member.

Mound evolution is accompanied by a change in flanking facies from bioclastic packstones and grainstones to breccias with reworked reef components. Gravitationally-induced failure of the early-cemented larger mounds generated penetrative networks of syndepositional fissures and breccia aprons; this did not occur in smaller reefs. These changes suggest a progressive increase of reef margin slope as the reef kept up with the accommodation space increase. As the pinnacle reef split up into isolated mounds at its top, it entered a give-up mode before drowning.

\section{4.b. Biostromes}

In contrast to bioherms, the biostromes developed during highstand systems tracts. A good example is preserved within the Omkyk Member, where a biostrome interfingers with several parasequences of amalgamated hummocky cross-stratified grainstones. The reefs 

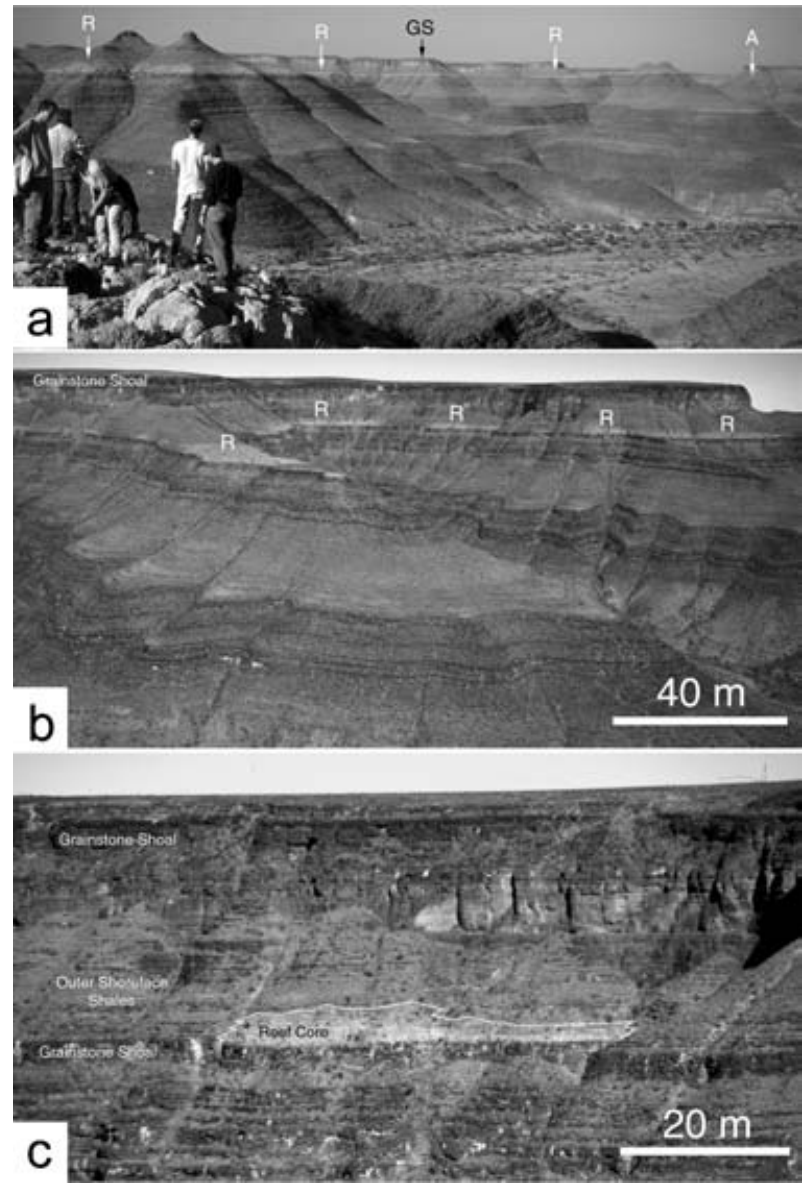

Figure 6. Reefs of the Zaris subbasin. (a) Laterally continuous thrombolite-stromatolite biostrome in updip (southeast) location within Donkergange. Photograph shows complete section through Omkyk Member of Kuibis Subgroup; basement crops out in far side of river valley. Note lateral continuity of light coloured unit ( $\mathrm{R}$ - reef) at top of Omkyk Member, which reflects selective dolomitization of reef facies relative to enclosing dark limestones and shales. Biostrome pinches out downdip (northwest) toward righthand side of photograph and is absent at 'A'. GS - grainstones within overlying Hoogland Member. The background distance, from ' $\mathrm{GS}$ ' to ' $\mathrm{A}$ ' is about $4 \mathrm{~km}$. (b) Further down dip the biostrome at top of Omkyk Member (see Fig. 5) passes laterally into discrete patch reefs, each indicated by an ' $R$ ' ( $R$ - reef). Reefs are overlain by deepwater shales, which in turn pass upward into a grainstone shoal complex. (c) Closeup of representative patch reef showing stratigraphic position immediately above a sequence boundary, which separates reef facies from underlying thick-bedded grainstone facies. Reef passes laterally into relatively thin-bedded shales and fine calcarenites. Note how bedding thickness decreases immediately above sequence boundary, indicating a regime of increasing accommodation.

are roughly $10 \mathrm{~m}$ thick (Fig. 7b). Biostromes and grainstone sheets generally can be traced over distances ranging from hundreds of metres to tens of kilometres. The reefs contain domal and columnar stromatolites, thrombolites and stromatolitic thrombolites. Stromatolite columns tend to be small and commonly occur in association with thick beds of cross-bedded grainstones
(Fig. 9), discussed below. In contrast, thrombolite columns are larger, closely spaced structures that often are stacked several metres high without interruption by terrigenous clastic sediment. Intercolumn fills contain dolomitized mudstones and cross-bedded CloudinaNamacalathus grainstones. Large domes of massive thrombolites, which are typical for the bioherm facies, are absent.

\section{Reef facies and diagenesis}

The general makeup of facies within both the Kuibis and Huns platforms indicates that deposition occurred on storm- to wave-dominated ramps. There is little evidence for tidal deposition, and most coarser facies show evidence for having accumulated under the influence of episodic, strong flows, often of oscillatory behaviour (O. Smith, unpub. M.Sc. thesis, Massachusetts Inst. Tech., 1999). The reefs formed part of an inner ramp facies assemblage (sensu Burchette \& Wright, 1992), representing the shallowest depositional environments, formed above fair weather wave base, including sand shoals, thrombolitic/stromatolitic buildups, and back-barrier lagoonal and peritidal deposits.

Thrombolites and stromatolitic thrombolites are the dominant microbial fabrics in the bioherm facies. They occur as domes and columns, as well as tufted and dendritic structures with centimetric to metric dimensions (Figs 9, 10). At their margins, the clotted thrombolites pass into stromatolite overgrowths and stromatolite columns that reach dimensions up to several decimetres (Fig. 9). Alternating layers of thrombolitic and stromatolitic fabrics and internal muddy to grainy sediment commonly are associated to form complex overgrowths that encrust the thrombolites.

The thrombolite biostrome facies consists of massive thrombolite, stratiform thrombolite and stromatolitic thrombolite, forming columns, branching columns and domes of generally decimetric to metric dimensions and decimetre-scale relief (Figs 9, 10). In general, the cores of domes and columns are characterized by a thrombolitic texture, whereas the margins become progressively more stromatolitic in nature, exhibiting crude lamination (Figs 9c, 10a). This marginal texture is best described as a stromatolitic thrombolite (Kennard \& James, 1986). In the Kuibis reefs, columns are consistently elongated with an azimuth of 270 $310^{\circ}$, normal to the palaeogeographic trend of the ramp (S. DiBenedetto, unpub. M.Sc. thesis, Massachusetts Inst. Tech., 2002; Adams et al. 2004).

Besides thrombolites, abundant stromatolite columns of generally centimetre to decimetre size with centimetre-scale synoptic relief occur in the biostrome facies (Figs 9, 10). Stromatolites usually are closely associated with thick beds of storm and wave crossbedded grainstones (Fig. 9). Grainstones commonly interrupt stromatolite growth, and they fill intercolumn spaces. 

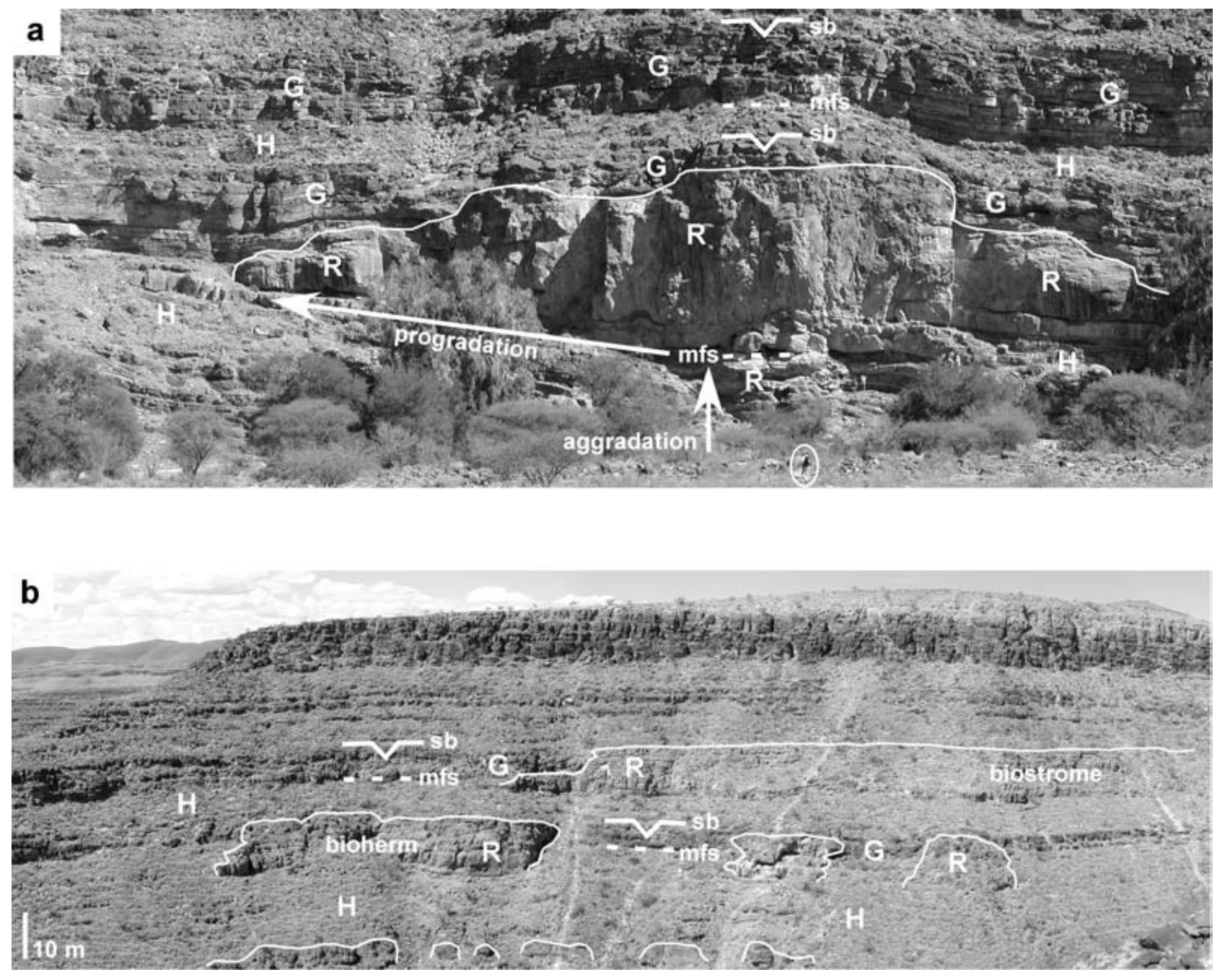

Figure 7. The evolution and geometry of microbial reefs is closely related to changes in accommodation within individual sequences. (a) Development of bioherms (R) commonly started in the TST part of a sequence. During this stage reefs aggraded, remained relatively small, and were associated with finer-grained heterolithic facies $(\mathrm{H})$. However, they expanded laterally with slowing of the rate of accommodation increase in the subsequent HST when reefs laterally passed into shallow-water grainstones (G). Shallow-water grainstones commonly onlap the tops of reefs. sb - sequence boundary, mfs - maximum flooding surface. (b) Outcrop panorama showing bioherms and a biostrome. The biostrome laterally interfingers with grainstones indicating a HST position for biostromes.

Body fossils are present within thrombolite domes and columns, and the intrachannel fill between domes and columns consists of a trough cross-bedded, fossiliferous packstone and grainstone of Namacalathus, Cloudina and their bioclastic detritus (Fig. 10a). These fossils range in size from millimetre-scale up to $2 \mathrm{~cm}$ in width. The thrombolitic cores of domes and columns contain fossils and fossil fragments up to $1 \mathrm{~cm}$ wide, whereas the stromatolitic rinds of domes and columns contain millimetre-scale fossils and fragments. Data that illustrate the strong relationship between fossil content and thrombolitic textures are shown in Figure 11. These data were obtained for a single stratigraphic section by binning into four facies groups all beds that contained fossils. Specifically, these data show that fossils are very strongly correlated with thrombolitic facies. Fossils are less abundant in packstones and grainstones, which are composed principally of intraclasts and peloids, and rare in mudstones. The simplest interpretation of this distribution is that the fossil organisms were benthic, with a strong preference for microbially colonized substrates. In addition, the preference for thrombolitic over stromatolitic substrates suggests further palaeoecological control on their distribution.

The biostrome facies characteristically developed as broad, laterally continuous reef complexes which became discontinuous down depositional dip into isolated bioherms and pinnacle reefs. In updip positions, ambient current velocities were high, as demonstrated by the occurrence of trough cross-bedded grainstone and the elongation of the stromatolitic thrombolite columns. The extremely consistent orientation of the thrombolite elongation is similar to other platforms where wave action is inferred to be responsible for the elongation of stromatolites (Hoffman, 1969; 

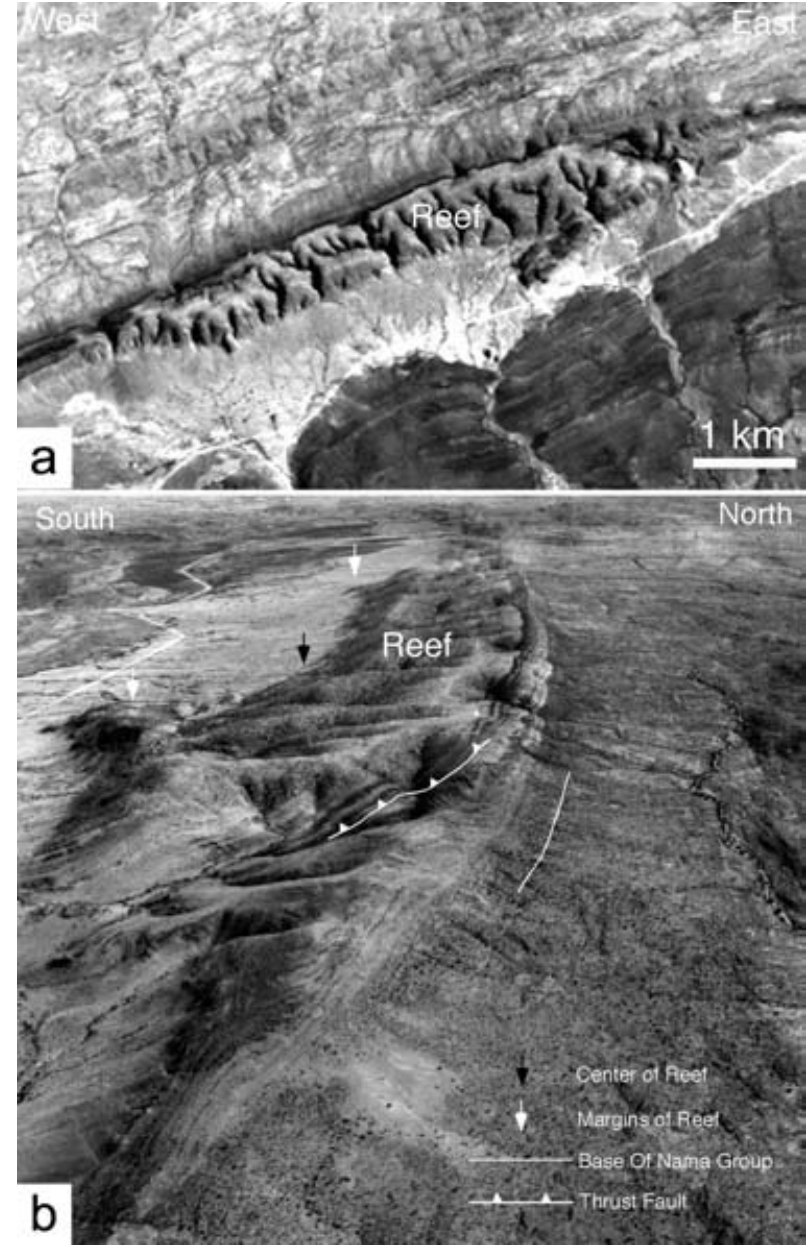

Figure 8. Large pinnacle reef (Driedoornvlakte buildup) on the Driedoornvlakte farm, Zaris subbasin. (a) Landsat TM image showing pinnacle reef developed on platform carbonates (dark grey line above ' $R$ ' in 'Reef') and overlain by deepwater shales (light grey, where road is located). The platform carbonates unconformably overlie much older quartzites (at top of photograph). Grey shades in the TM image map composition well: reef has light grey tone which reflects high dolomite content, whereas dark grey tone (thin layer above 'R' in 'Reef') of shallow-water platform carbonates reflects dominance of limestone. Rocks have structural dip of about $40^{\circ}$ toward south. (b) Low-altitude, oblique aerial photograph of Driedoornvlakte buildup. Note regional structural dip of $40^{\circ}$ toward south. Minor folding and a low-displacement thrust fault disrupts eastern part of outcrop. White arrows point to sides of reef, which would have been topographically higher than the centre of reef (black arrow) suggesting that it may have had a 'bucket' geometry with raised rim.

Cecile \& Campbell, 1978; Grotzinger, 1986), analogous to the development of 'spur and groove' structure in modern coral reefs (Shinn, 1963; Sneh \& Friedman, 1980). In downdip positions, ambient current velocities also were high, again demonstrated by the presence of cross-bedded grainstone within thrombolitic buildups. However, in these latter cases the reefs kept up with relative sea-level rise, whereas the inter-reef regions accumulated sediment under much reduced current velocities at greater water depths. Inter-reef water depths are estimated to have been on the order of tens of metres for the Huns pinnacle reefs and hundreds of metres for the Driedoornvlakte buildup. The waterdepth estimate for the Driedoornvlakte buildup was calculated based on its maximum thickness, by noting that the bioherm is completely encased in shales, and that no shale occurs within the reef. Thus, it is concluded that the shale was deposited after the reef had already formed and that the bioherm's thickness is an accurate estimate of its true depositional relief.

This interpretation supports other evidence that the Kuibis ramp was a wave- and storm-dominated system, where the dominant currents were induced by strong wave-generated flows. The particular values for the stromatolite elongation (Adams et al. 2004) indicate consistent oscillation by waves arriving from the WNW, the direction of the Damara-Gariep orogenic belt, and may imply an orographic effect that might have influenced the entire foreland basin (Hoffman \& Grotzinger, 1993).

The internal texture of the thrombolite reefs is distinct. It is characterized by mesoclots that range in size from a few millimetres to a few centimetres in diameter (Figs 9, 10, 12). Curiously, the mesoclots of the Nama reefs do not have the complex digitate or dendriform morphologies that characterize younger thrombolites (e.g. Kennard \& James, 1986; Riding \& Zhuravlev, 1995), but instead are restricted to simpler ovoid, globular and colliform morphologies (Figs 9, 10, 12). These simpler morphologies also are common in Palaeozoic and Mesozoic thrombolites but are the only forms described from older Proterozoic thrombolites (Kah \& Grotzinger, 1992; Turner, Narbonne \& James, 1993). However, this difference in mesoclot morphology could also correlate with differences in environment, and more work is required to clarify this distinction.

Nama mesoclots formed an open framework that resulted in development of abundant cavities (Figs 9, 10, 12). Mesoclots typically were overgrown by a synsedimentary crust of fibrous marine cement with botryoidal geometry that now consists of calcite but is interpreted to have replaced former aragonite (Fig. 12). This interpretation of original mineralogy is based on the presence of botryoidal growth form of crystal aggregates, square-tipped crystal terminations and the complete loss of internal texture within the botyroids (Sandberg, 1985). Marine cement crusts were then overlain by a layer of geopetal sediment, which partially filled framework pores (Figs 9d, 10b, 12). Remaining porosity was then occluded by a dolomite rim cement, followed by blocky calcite spar (Fig. 12). Mesoclots characteristically are recrystallized to an extent that makes interpretation of growth processes difficult. Figure 12a shows an example of the more poorly preserved mesoclots, whereas Figure $12 \mathrm{~b}$ shows a well-preserved example. Note that Figure 12 shows 

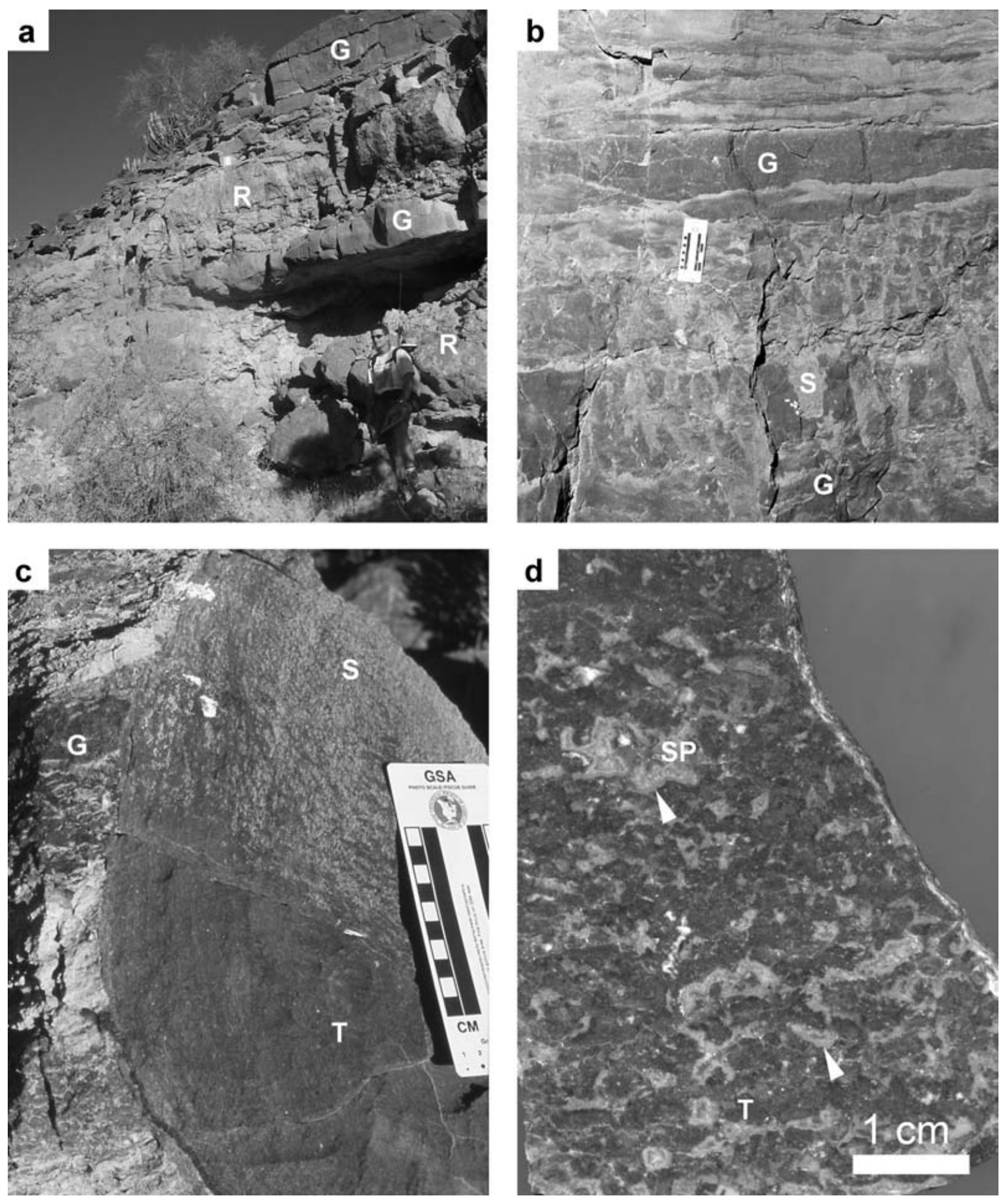

Figure 9. Representative photographs of microbialites and associated textures. (a) Biostrome (R) interfingering with shallow-water grainstones $(\mathrm{G})$. (b) Biostrome facies showing stromatolite columns (S) overlain by shallow-water grainstones (G). Grainstones also fill intercolumn space. (c) Thrombolite dome with both massive clotted thrombolite fabric $(\mathrm{T})$ and more laminated, stromatolitic fabric (S). Skeletal grainstones (G) occur between domes. (d) Clotted thrombolite fabric (T) with geopetal sediment (arrows) and shelter porosity filled by calcite cement (SP).

the lower part of the same rock shown in Figure 12a, illustrating the strong gradients in textural preservation. Locally, mesoclots in the better-preserved samples show tentative evidence of having been formed in the presence of coccoid cyanobacteria or algal spores, expressed as poorly preserved spherical objects present 


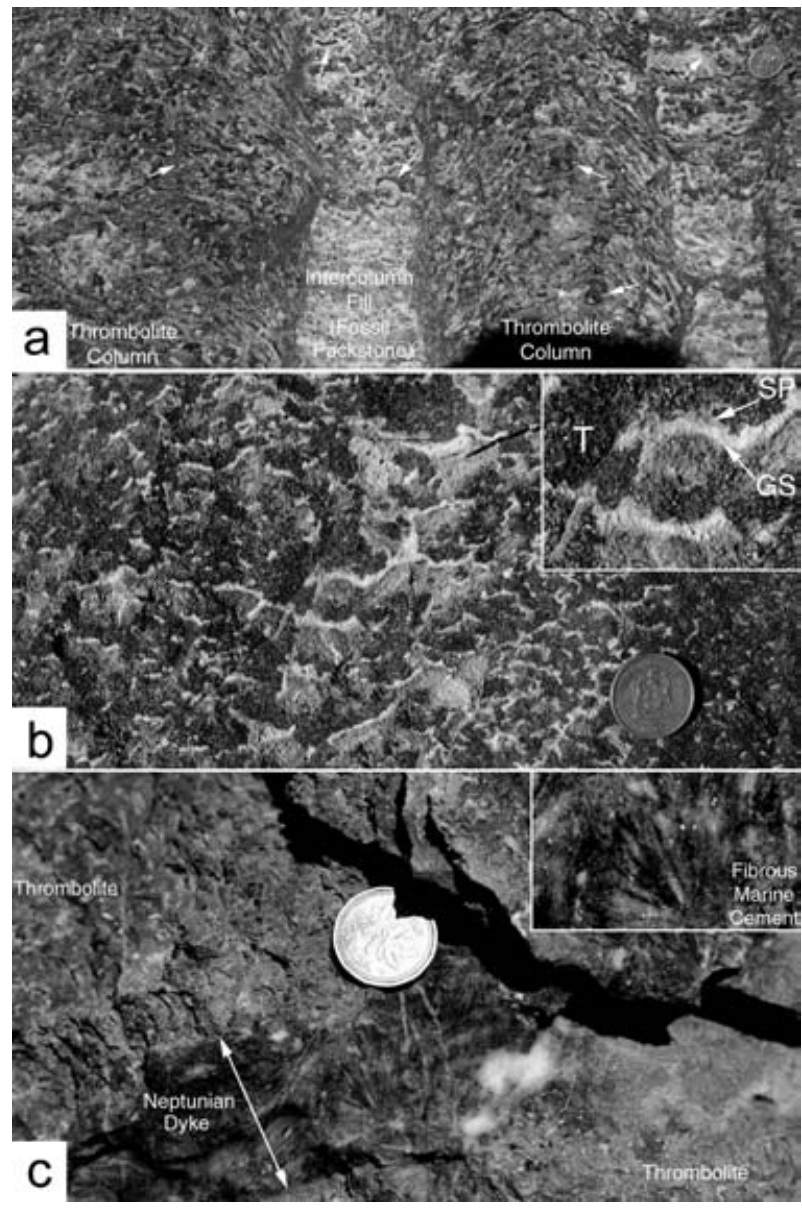

Figure 10. Representative photographs of microbialites and associated textures. (a) Stromatolitic thrombolite columns forming laterally continuous biostrome at top of Omkyk Member, Zaris subbasin. Core of each column has dominantly thrombolitic texture, whereas margins have better-laminated stromatolitic thrombolite texture. Columns are stongly elongate normal to the trend of the Omkyk carbonate ramp indicating persistent highvelocity, wave-generated flows. Arrows point to Namacalathus and Cloudina fossils that are abundant within the intercolumn fill sequences, but also trapped within the thrombolitic texture. Coin is approximately $1.2 \mathrm{~cm}$ in diameter. (b) Well-preserved thrombolite texture in pinnacle reef at top of Huns platform, Witputs subbasin. Reefal framework is created by dark-coloured mesoclots; these create shelter pores that are partially filled by light-coloured geopetal sediment and ultimately filled by fibrous marine and later blocky, burial cements. Inset shows fabric details; T - thrombolite mesoclot; GS - geopetal sediment; SP shelter porosity filled with cement. Coin is approximately $1.2 \mathrm{~cm}$ in diameter. Inset shows enlargement of region near centre of photograph. (c) Neptunian dyke transecting thrombolite mound, Driedoornvlakte buildup, Zaris subbasin. Dyke is infilled with botryoidal fibrous calcite cement, interpreted to have replaced primary aragonite. Cements fill fractures within reef, providing evidence for early lithification of reef. Coin is approximately $1 \mathrm{~cm}$ in diameter. Inset shows enlargement of region below coin.

only in the cores of mesoclots (see white arrow, lower right in Fig. 12c).

Early lithification of thrombolites and stromatolites in the Huns and Driedoornvlakte buildups, followed

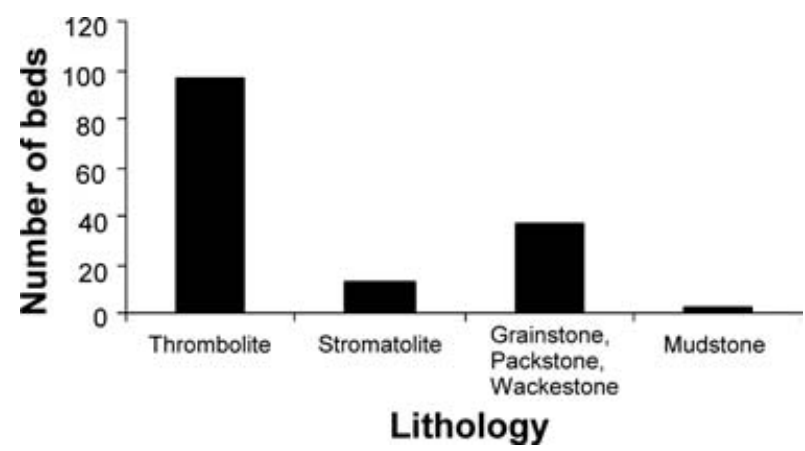

Figure 11. Distribution of calcified fossils within broadly defined lithological facies of the Nama Group. See text for discussion.

by gravitational failure of the large reef mounds, resulted in development of penetrative networks of syndepositional fissures that cut sharply across reefs (Figs 10c, 13b). Fissures are filled with formerly aragonitic botryoids, breccias and bioclastic grainstones. In the Driedoornvlakte buildup, some fissures are encrusted by Namapoikia rietoogensis (Wood, Grotzinger \& Dickson, 2002). Because of their greater syndepositional relief and steeper margin slopes, the larger mounds are frequently flanked by slide breccias (Fig. 13c; see also Adams et al. 2004). These breccias are composed of angular blocks up to $1 \mathrm{~m}$ in diameter with thrombolite and stromatolite textures. Voids between breccia blocks are filled with massive lime or dolomite mudstones, or fibrous marine cements.

\section{Associated facies}

Grainstones are closely associated with thrombolite reefs in the Nama Group. The geometry of grainstone bodies varies with stratigraphic position and occurs in the form of extensive sheets or as local lenses within the reef framework. Grainstones formed in the HST of sequences in the middle and upper Omkyk Member have sheet-like geometry due to their accumulation under conditions of decreasing accommodation. These grainstones commonly form the platform on which the reefal biostromes of the middle and upper Omkyk were built as part of the overlying TST. For example, the major buildup at Driedoornvlakte (Figs 5,8) was established on a thick interval of grainstone (O. Smith, unpub. M.Sc. thesis, Massachusetts Inst. Tech., 1999), even though this site is the most downdip position preserved in the Nama Group. Relations are similar for more updip positions; Figure 6c shows laterally continuous, relatively thick-bedded grainstone deposits beneath a small, updip patch reef.

Grainstones in this stratigraphic setting consist mostly of very fine- to medium-grained grainstones characterized by planar stratification, quasiplanar stratification (Arnott, 1993), hummocky cross-stratification, wavy bedding, ripple cross-bedding and trough 

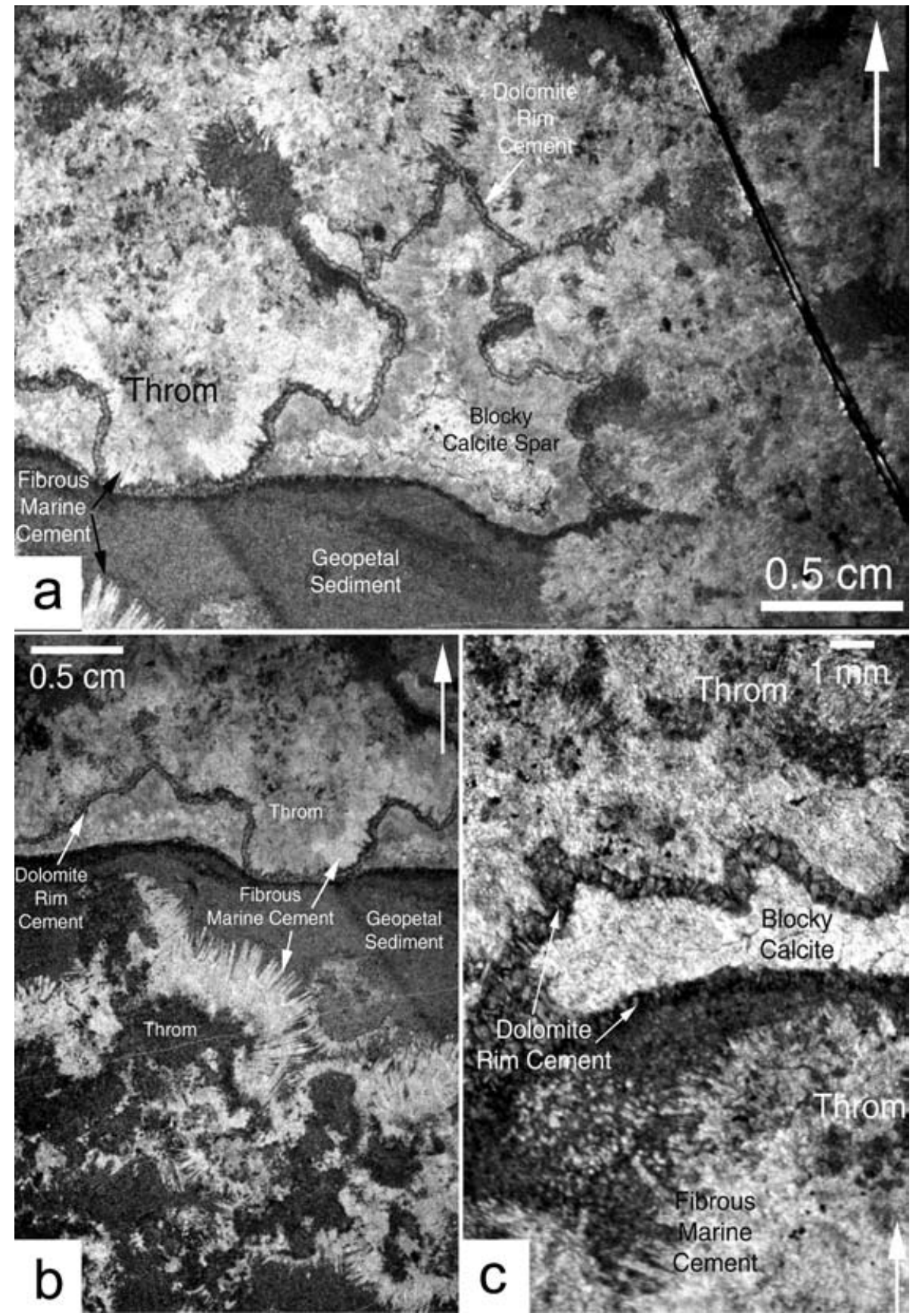

Figure 12. Thin-section photomicrographs of thrombolite fabrics within pinnacle reef at top of Huns carbonate platform, Witputs subbasin. (a) Thin-section shows poorly preserved mesoclots (Throm) encrusted with a fringe of fibrous calcite (Fibrous Marine Cement) interpreted to have replaced original aragonite (note square crystal terminations). This was followed by deposition of a layer of silt-sized crystals (Geopetal Sediment). Occlusion of remaining shelter porosity began with precipitation of an isopachous fringe of Dolomite Rim Cement, followed by a final infill of Blocky Calcite Spar. Note that Dolomite Rim Cement is grown in contact with Fibrous Marine Cement or Geopetal Sediment depending on its location. (b) Thin-section of thrombolite with wellpreserved mesoclots (Throm) composed of distinct aggregates of smaller clots. These smallest fabric elements most likely are formed by the early cementation of a complex consortium of mat-building cyanobacteria, heterotrophic bacteria and eucaryotic algae. Note the accumulation of Geopetal Sediment (crystal silt) which smoothes out the rugged relief created by the clots and encrusting fibrous marine cements. As in Figure 12a, note presence of isopachous Dolomite Rim Cement and porosity-occluding blocky calcite. (c) Magnified view showing textural detail of thrombolite mesoclots. In particular, note the mesoclot between the arrow tip and 'Throm' which shows several circular cross-sections that may be fossils of coccoid cyanobacteria or eucaryotic algal spores.

cross-bedding (Fig. 14a). Grains In this stratigraphic position consist dominantly of peloids, small intraclasts and coated peloids (Fig. 14b), and uncommon frag- ments of Cloudina and Namacalathus fossils. These shoal facies are interpreted to have been deposited in moderately high-energy conditions, with occasional 


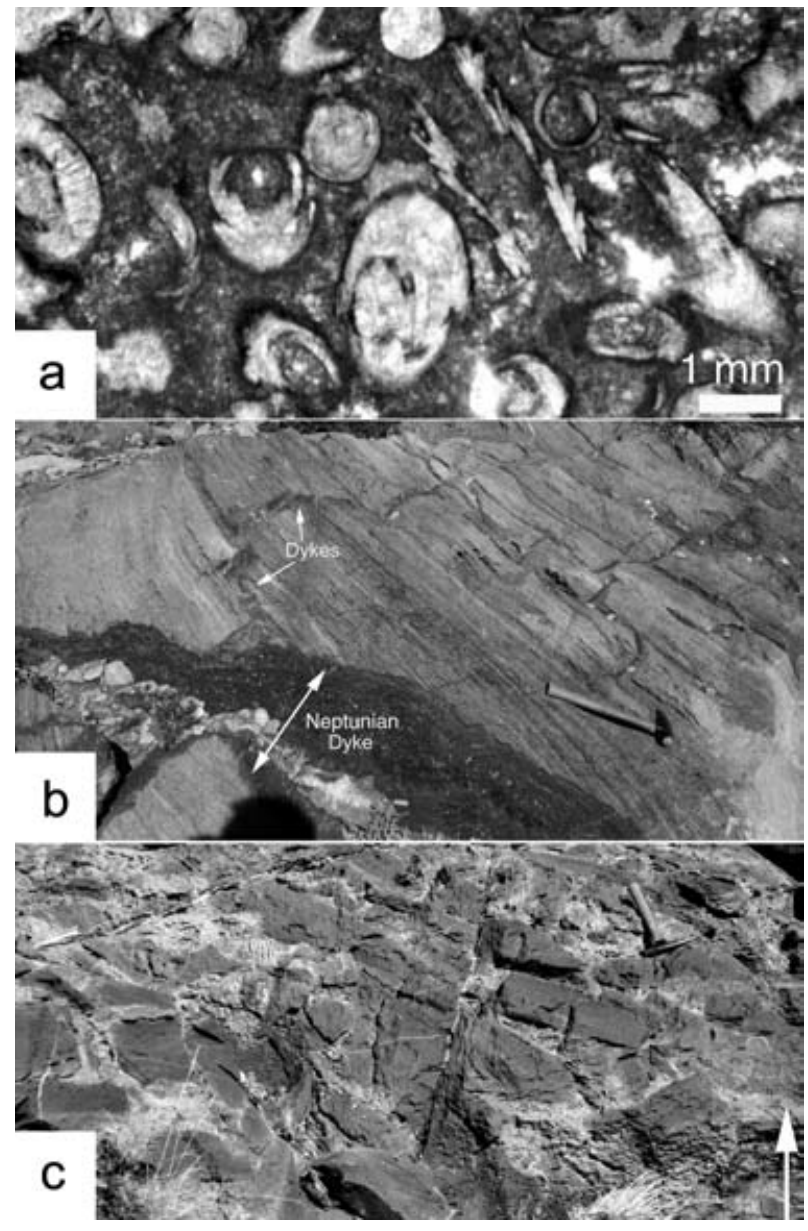

Figure 13. Associated reef facies. (a) Cloudina packstone forming bioclastic detritus at top of Driedoornvlakte buildup. Note specimen near centre of photograph which shows longitudinal cross-section, revealing that Cloudina consists of series of stacked flanges rather than cones. (b) Sets of neptunian dykes cross-cutting stromatolitic facies within pinnacle reefs at top of Huns platform, Witputs subbasin. Neptunian dykes are filled with marine cement. The presence of these dykes indicates fracturing of early-cemented reefal structures, which often collapsed to form piles of breccia with reef (see Fig. 13c). Hammer is $35 \mathrm{~cm}$ long. (c) Collapse breccia at base of pinnacle reef at top of Huns platform. Angular blocks indicate early lithification of the reef, consistent with evidence for fracturing and infilling with marine cement (see Fig. 13b). Arrow indicates stratigraphic up direction. Hammer is $35 \mathrm{~cm}$ long.

periods of quiescence. The presence of quasiplanar stratification and hummocky cross-stratification indicates that these sediments were transported during episodic strong flows, probably of combined unidirectional and oscillatory nature (Southard et al. 1990; Arnott, 1993). This evidence points to reworking in the presence of storms; fairweather waves may have been primarily responsible for lower velocity flows leading to development of trough cross-bedding and ripple crossstratification.

Grainstones forming lenses within reefs have significantly different attributes. First, because of their
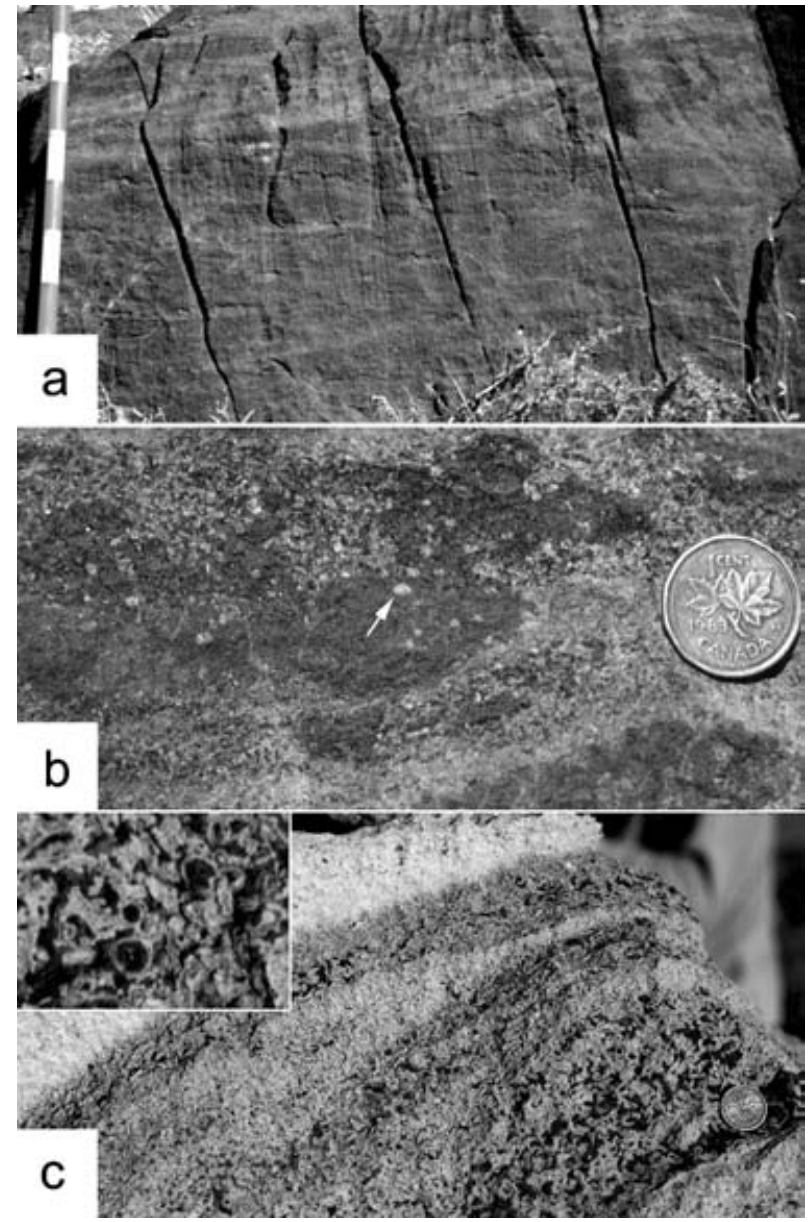

Figure 14. Associated grainstone facies. (a) Cross-bedded intraclast-peloid-skeletal grainstone near top of Omkyk Member, Zaris subbasin, a few metres below thrombolite-stromatolite biostrome. Cross-beds indicate shallow, high-velocity flows on a wave- and storm-dominated shoal. The reefal biostrome developed on top of this shoal during accommodation increase and relative sea-level rise. Rod subdivided in $10 \mathrm{~cm}$ intervals. (b) Close-up of grainstone shown in Figure 10a, showing individual coarse grains consisting of intraclasts and coated grains. Arrow points to leached intraclast filled with blocky spar. Coin is approximately $1 \mathrm{~cm}$ in diameter. (c) Cloudina grainstone-packstone formed at top of Driedoornvlakte buildup. Inset shows details of skeletal structure and dark, void-filling marine cement. Accumulations of Cloudina are best developed near the tops of the reefs, within the bases of stratigraphic flooding intervals where accommodation greatly out-paced sediment supply. In this stratigraphic position, skeletal debris accumulates between the growing thrombolite-stromatolite mounds. Coin is approximately $1 \mathrm{~cm}$ in diameter.

stratigraphic position within the TST, under conditions of increasing accommodation, they form discontinuous lenticular bodies which interfinger with the reefal facies (Fig. 9a, b). Compositionally, the grains consist dominantly of skeletal fragments representing broken specimens of Cloudina (Figs 13a, 14c) and Namacalathus (see Grotzinger, Watters \& Knoll, 2000), in addition to peloids and intraclasts. 


\section{Discussion}

\section{7.a. Effect of accommodation changes}

The above relationships illustrate how the development and growth of Nama Group reefs were related to accommodation changes and sediment flux. Aggradational bioherm growth was favoured by increased accommodation and lowered sediment flux that occurred during TST to early HST development. This is analogous to younger, metazoan-dominated bioherms (cf. Burchette \& Wright, 1992; Tucker, Calvet \& Hunt, 1993), as well as other Proterozoic reefs (Jackson \& Iannelli, 1989; Narbonne \& James, 1996; Turner, James \& Narbonne, 1997). At the same time, the large pinnacle reefs were able to track sea level. This is clearly illustrated by the Driedoornvlakte example where up-section changes in mound size, syndepositional fissures and associated flank sediment suggest a gradual increase of reef topography before the accommodation increase outpaced reef growth and caused drowning.

In contrast, biostromes developed when accommodation space was limited in a HST situation and did not allow for significant aggradational growth. Furthermore, increased sediment flux in shallow-water, high-energy environments interfered with and limited microbial growth, as shown by small stromatolites covered by grainstones (Grotzinger \& Knoll, 1999).

\section{7.b. Genesis of thrombolite fabric}

The Nama Group contains one of the earliest assemblages of reef-forming microbialites and metazoans. These reefs appear at a critical time in Earth history, immediately prior to the dramatic radiation of metazoans in early Cambrian time. Consequently, this motivates discussion of several aspects of this important association, including the significance of thrombolite textures, the palaeoecological interactions between metazoans and microbialites, and the functional morphology and phylogenetic affinity of the calcified metazoan fossils. Only the first two of these issues is addressed here; the latter two are discussed in Grotzinger, Watters \& Knoll (2000) and Wood, Grotzinger \& Dickson (2002).

The origin of thrombolite textures and the buildups they form have been long debated. Aitken (1967) first coined the term 'thrombolite' to refer to rocks formed of a distinctive class of textures of inferred microbial origin, which were distinctly clotted rather than laminated in appearance, and thus of potentially different origin from stromatolites.

Thrombolitic textures have been variably interpreted over the years, but in all cases it has been recognized that they are very rare in rocks that are older than Neoproterozoic in age (cf. Kah \& Grotzinger, 1992), and first appear in abundance at or close to the Precambrian-Cambrian boundary. Thus, most interpretations of thrombolites feature explanations rooted in some aspect of the Cambrian radiation or the environmental state of the Earth at that time. For example, the initial interpretation of Aitken (1967), who invoked a microbial origin for the thrombolite clots, was challenged by Walter \& Heys (1984), who argued that thrombolite clots were the aftermath of burrowing of ordinary stromatolites by organisms that evolved in the late Neoproterozoic time. They linked this to the simultaneous decline of stromatolites during Neoproterozoic time, accounted for in their model by the burrowing and grazing activities of the first macroscopic metazoans. Other models for the decline of stromatolites at this time include changes in ocean chemistry and competitive exclusion by higher algae (summarized in Grotzinger, 1990; Grotzinger \& Knoll, 1999).

Following the work of Walter and Heys (1984), it was shown that Palaeozoic (Kennard \& James, 1986) and even rare Palaeoproterozoic (Kah \& Grotzinger, 1992) thrombolite textures do not result from the activities of burrowing and grazing metazoans and instead are formed as a primary, likely microbially influenced facies, supporting the original inference of Aitken (1967). Kennard \& James argued that the diagnostic clotted fabric of thrombolites is generated by in situ calcification of discrete growth forms of coccoiddominated microbial communities. Kah \& Grotzinger (1992) argued a similar point, but invoked encrustation of colloform, coccoid-dominated microbial mats by marine cement, rather than micritic calcification of individual microbes in the manner proposed by Kennard \& James (1986). In either case, the point is that coccoid cyanobacteria form very rough, irregular mats (Golubic \& Hofmann, 1976) that, when lithified, will create a clotted texture with only crude lamination. More recent work also supports this interpretation for Neoproterozoic thrombolites (Turner, James \& Narbonne, 1997).

Most recently, it has been suggested that Palaeozoic thrombolites may result from the participation of higher algae and metazoans in the mat-building consortium (Feldmann \& McKenzie, 1998). This inference is based on the observation that modern procaryotic communities produce well-developed lamination in intertidal environments, whereas eucaryotic communities, including green algae, produce poorly laminated, thrombolitic textures in open-marine subtidal environments. This interpretation is consistent with the many observations of Palaeozoic thrombolites that support their growth in subtidal environments (Aitken, 1967; Bova \& Read, 1987; Pratt \& James, 1986), and that they appear in the historical record at about the same time that macroscopic algae are first preserved (Knoll, 1992). Significantly, the Nama record of thrombolites can be queried as a test of this hypothesis.

Observations of the thrombolites in the Nama Group are consistent with the predictions of the model of Feldmann \& McKenzie (1998). Nama thrombolites 
formed in open-marine, wave-swept environments, often associated with grainstone shoals, and occur mainly in bioherms set within a stratigraphic position consistent with accommodation increase and sea-level rise. Well-laminated stromatolites are less common in the Nama group, but so are intertidal facies. Nevertheless, the best stromatolites are developed as columns within the sheet-like biostromal units (Figs 6, $9 \mathrm{~b}, 10 \mathrm{a})$ which are interpreted to have formed in a very shallow subtidal environment. These relationships suggest a gentle depth zonation with stromatolites forming in shallower water than thrombolites (cf. Pratt \& James, 1982). Interestingly, the margins of the columns are much better laminated than the cores, suggesting that sediment abrasion may have influenced the column texture. Feldmann \& McKenzie (1998) indicated that high sediment bombardment restricts the distribution of eucaryotic mat components, favouring procaryote-dominated communities and better lamination. Eucaryotes tend to colonize sites with lower sediment flux, including the lee sides of columns and their tops. This is consistent with the relationships seen in Figure 10a, where the cores would have been palaeotopographically higher (clotted texture) than the margins (laminated texture) based on tracing laminae that define synoptic profiles.

Significantly, thrombolite textures are most abundant and best developed within the Nama pinnacle reefs at the top of the Huns platform and at Driedoornvlakte. The reefs are composed of large mounds, which are rarely elongate; where elongation is developed it is defined by a low length-to-width ratio, consistent with low current velocities in deeper water subtidal settings. The thrombolite textures developed in this setting are extremely similar to those of Palaeozoic age (compare Figs 9d, 10b of this paper with fig. 2b in Kennard \& James, 1986), and at the same time somewhat different from those illustrated by Feldmann \& McKenzie (1998) from the modern eucaryote-dominated columns of the Bahamas.

Some of the differences between the Nama thrombolites and Bahamian thrombolites include the lack of cylindrical voids created by boring metazoans, and the larger size of mesoclots. The absence of borings along the margins of Nama thrombolites is most simply related to the absence of organisms during terminal Proterozoic time that had the capacity to form tubes comparable in size to those seen in the Bahamian thrombolites (1-2 mm; see fig. 8 of Feldmann \& McKenzie, 1998); however, it has been noted that microboring organisms may have been present in rocks of this age, as shown by the presence of possible predation holes in Cloudina shells (Bengtson \& Zhao, 1992).

Mesoclots in the Nama thrombolites (up to $1.5 \mathrm{~cm}$ in diameter) are distinctly larger than those in the Bahamian thrombolites (a few millimetres in diameter). Accounting for this size difference must lie in elucidating the mechanism by which clots are formed. Kennard \& James (1986) invoked calcification of coccoid-dominated microbial communities, but Feldmann \& McKenzie (1998) emphasized the limited evidence from modern mats which supports that interpretation. Instead they argued that a consortium of procaryotes, algae and their spores, and metazoans including sponges, could have triggered precipitation of micrite within an organic framework to form irregularly-shaped mesoclots. This mechanism is attractive in accounting for the Nama thrombolites in that it is almost certain, on the basis of the fossil record, that green and brown algae (Knoll, 1992), and possibly sponges (Brasier, Green \& Shields, 1997), were present at that time. However, the exact roles that these organisms had in inducing carbonate precipitation remain vague at this time.

\section{7.c. Thrombolite reefs and calcified metazoans}

A final point concerns the role of the Nama calcified metazoans in reef development. Cloudina, Namacalathus and Namapoikia have a strong affinity for thrombolitic substrates (Fig. 11; Grotzinger, Watters \& Knoll, 2000; Wood, Grotzinger \& Dickson, 2002). On the basis of their very restricted facies distribution, these organisms must have been benthic in origin, with a very strong preference for firm, relatively sediment-free substrates that built thrombolites. However, they did not participate in any substantial way in reef building, either as framebuilders or sediment bafflers. They are best interpreted to have lived as solitary individuals, apparently attached by the stem end in the case of Namacalathus (see Grotzinger, Watters \& Knoll, 2000 for detailed discussion of fossil morphologies). Cloudina appears to have been attached not by its end, but rather with its shell parallel to the microbial substrate, perhaps partially embedded within it (J. Grotzinger, unpub. data). In this mode it is straightforward to visualize a palaeoecological reconstruction in which the calcified organisms were loosely attached to the accreting thrombolitic substrate, much in the same way that sponges and green algae do in the Bahamian thrombolites. Somewhat paradoxically, however, if Namacalathus individuals were attached to the thrombolite substrate, it has been very difficult to find individuals preserved in growth position. In one or two cases there are some hints of this, but nothing compelling has been discovered so far. One would presume that under the condition of progressive accretion of the thrombolitic substrate, at least occasional individuals would be trapped and accreted in growth position. In fact, Namacalathus fossils in general are not abundant in the Nama thrombolite columns and where they do occur they are not preserved in growth position. Consequently, an alternative interpretation of Namacalathus growth habit and fossil distribution can be accounted for by allowing 
for attachment, as epibionts, to the green and/or brown algae that were likely widespread on the terminal Proterozoic seafloor (Butterfield, Knoll \& Swett, 1988), probably including thrombolitic substrates. Upon death or dislocation of the algal components the calcified organisms would have collapsed to the sea floor as detrital particles and been simply swept into the depressions between thrombolite columns and mounds, or occasionally trapped in random positions within the accreting mats. This interpretation also provides a mechanistic basis for understanding the locally great abundance of randomly scattered fossils in thin (a few centimetres) beds of thrombolitic laminites that form spatially extensive sheets within deeper subtidal facies. Indeed, before the radiation of predating metazoans it is possible to envision broad expanses of the terminal Proterozoic seafloor which would have been best characterized as microbialalgal 'carpets', with these earliest calcified metazoans inhabiting densely populated stands of brown and green algae.

Namapoikia also has a distinct relationship with thrombolite mounds. However, it occurs as an encruster, dominantly lining the margins of neptunian dykes but also, in rare cases, encrusting the surface of thrombolite mounds (Wood, Grotzinger \& Dickson, 2002). In addition, Namapoikia differs from Cloudina and Namacalathus in that it may have been a colonial organism (Wood, Grotzinger \& Dickson, 2002).

Whatever the current uncertainties in understanding the environmental and phylogenetic affinities of these fossils, it is clear that the Nama Group holds the potential, distributed over more than 10000 square kilometres of some of the world's best outcrop, for answering these important questions. The broad expanse of the Nama Group has just started to be tapped. It is certain that the next decade of work will provide important additional discoveries that will test the various hypotheses for the origin of thrombolitic textures, their significance as recorders of Earth evolution, and in providing important habitats for the earliest biomineralized metazoans.

Acknowledgements. The Geological Survey of Namibia is gratefully acknowledged for providing a field vehicle and logistical support for many years of research in Namibia. Wolf Hegenberger, Charlie Hoffman and Roger Swart are thanked for help in providing an introduction to the geology of Namibia, and for providing helpful guidance and advice. Roger Swart and NAMCOR are thanked for providing the Landsat TM image in Figure 8. Special thanks go to Rob and Marianne Field and Roy Magson for access to their farms, Zebra River and Donkergange, and for their hospitality. Support for this research was provided by NSF grants EAR-9904298 and EAR-0001018. Maurice Tucker and Rachel Wood are acknowledged for helpful reviews of the manuscript.

\section{References}

ADAMS, E. W., SchröDER, S., GROTZINGER, J. P. \& MCCORMICK, D. S. 2004. Digital reconstruction and stratigraphic evolution of a microbial-dominated, isolated carbonate platform (terminal Proterozoic, Nama Group, Namibia). Journal of Sedimentary Research 74, 479-97.

AitKen, J. D. 1967. Classification and environmental significance of cryptalgal limestones and dolomites, with illustrations from the Cambrian and Ordovician of southwestern Alberta. Journal of Sedimentary Petrology 37, 1163-78.

AMTHOR, J. E., GROTZINGER, J. P., SCHRÖDER, S., BOWRING, S. A., Ramezani, J., Martin, M. W. \& Matter, A. 2003. Extinction of Cloudina and Namacalathus at the Precambrian-Cambrian boundary in Oman. Geology 31, 431-4.

ARNOTT, R. W. C. 1993. Quasi-planar-laminated sandstone beds of the Lower Cretaceous Bootlegger Member, north-central Montana: Evidence of combined-flow sedimentation. Journal of Sedimentary Petrology 63, 48894.

Bengtson, S. \& ZhaO, Y. 1992. Predatorial borings in late Precambrian mineralized exoskeletons. Science 257, 367-9.

Bova, J. P. \& READ, J. F. 1987. Incipiently drowned facies within a cyclic peritidal ramp sequence, Early Ordovician Chepultepec interval, Virginia Appalachians. Geological Society of America Bulletin 98, 714-27.

Bowring, S. A., Grotzinger, J. P., IsAChSEN, C. E., Knoll, A. H., Pelechaty, S. M. \& Kolosov, P. 1993. Calibrating rates of Early Cambrian evolution. Science 261, 1293-8.

Butterfield, N. J., Knoll, A. H. \& Swett, K. 1988. Exceptional preservation of fossils in an Upper Proterozoic shale. Nature 334, 424-7.

Brasier, M., GreEN, O. \& SHIELdS, G. 1997. Ediacaran sponge spicule clusters from southwestern Mongolia and the origins of the Cambrian fauna. Geology 25, 303-6.

Burchette, T. P. \& Wright, V. P. 1992. Carbonate ramp depositional systems. Sedimentary Geology 79, 357.

Cecile, M. P. \& Campbell, F. H. A. 1978. Regressive stromatolite reefs and associated facies, middle Goulburn Group (Lower Proterozoic) in Kilohigok Basin, N. W. T.: an example of environmental control on stromatolite forms. Bulletin of Canadian Petroleum Geology 26, 237-67.

DiBenedetto, S. \& Grotzinger, J. 2005. Evolution of a storm-dominated carbonate ramp, Hoogland Member (c. 549 Ma), Nama Group, Namibia. Geological Magazine 142, 000-000.

FELDMANN, M. \& MCKenZIE, J. 1998. Stromatolitethrombolite associations in a modern environment, Lee Stocking Island, Bahamas. Palaios 13, 201-12.

GERMS, G. C. B. 1974. The Nama Group in South West Africa and its relationship to the Pan African Geosyncline. Journal of Geology 82, 301-17.

Germs, G. J. B. 1972a. New shelly fossils from the Nama Group, South West Africa. American Journal of Science 272, 752-61.

GERMS, G. J. B. 1972b. The stratigraphy and paleontology of the lower Nama Group, South West Africa. Bulletin of the Precambrian Research Unit 12, 250 pp. 
GERMS, G. J. B. 1983. Implications of a sedimentary facies and depositional environmental analysis of the Nama Group in South West Africa/Namibia. In Evolution of the Damara Orogen (ed. R. M. Miller), pp. 89-114. Geological Society of South Africa, Johannesburg.

Golubic, S. \& HofmanN, H. J. 1976. Comparison of modern and mid-Precambrian Entophysalidaceae (Cyanophyta) in stromatolitic algal mats: cell division and degradation. Journal of Paleontology 50, 1074-82.

GRANT, S. W. F. 1990. Shell structure and distribution of Cloudina, a potential index fossil for the terminal Proterozoic. American Journal of Science 290-A, 26194.

Grant, S. W. F., Knoll, A. H. \& Germs, G. J. B. 1991. Probable calcified metaphytes in the latest Proterozoic Nama Group, Namibia. Journal of Paleontology 65, 118.

Gresse, P. G. \& Germs, G. J. B. 1993. The Nama foreland basin: sedimentation, major unconformity bounded sequences and multisided active margin advance. Precambrian Research 63, 247-72.

GROTZINGER, J. P. 1986. Evolution of early Proterozoic passive-margin carbonate platform, Rocknest Formation, Wopmay Orogen, N. W. T., Canada. Journal of Sedimentary Petrology 56, 831-47.

GROTZINGER, J. P. 1989. Facies and evolution of Precambrian carbonate depositional systems: emergence of the modern platform archetype. In Controls on Carbonate Platform and Basin Development (eds P. D. Crevello, J. L. Wilson, J. F. Sarg and J. F. Read), pp. 79-106. Society of Economic Paleontologists and Mineralogists, Special Publication no. 44. Tulsa.

Grotzinger, J. P. 1990. Geochemical model for Proterozoic stromatolite decline. American Journal of Science 290-A, 80-103.

GrotzingeR, J. P. 1994. Trends in Precambrian carbonate sediments and their implication for understanding evolution. In Early Life on Earth (ed. S. Bengtson), pp. 245-58. New York: Columbia University Press.

GrotZINGER, J. P. 2000. Facies and paleoenvironmental setting of thrombolite-stromatolite reefs, terminal Proterozoic Nama Group (ca. 550-543 Ma), central and southern Namibia. Communications of the Geological Survey of Namibia 12, 221-33.

Grotzinger, J. P., Bowring, B. Z., SAYlor, B. Z. \& KAUFMAN, A. J. 1995. Biostratigraphic and geochronologic constraints on early animal evolution. Science $\mathbf{2 7 0}$, 598-604.

Grotzinger, J. P. \& JAMES, N. P. 2000. Precambrian Carbonates: Evolution of Understanding. In Carbonate Sedimentation and Diagenesis in the Evolving Precambrian World (eds J. Grotzinger and N. James), pp. 3-22. Society of Economic Paleontologists and Mineralogists, Special Publication no. 67. Tulsa.

Grotzinger, J. P. \& Khetani, A. 1994. Facies and diagenesis of late Vendian thrombolite-shelly (Cloudina?) invertebrate pinnacle reefs, Nama Group, Namibia. In Abstracts with Programs (Northeast Section), p. 56. Boulder: Geological Society of America.

Grotzinger, J. P. \& KnOll, A. H. 1999. Stromatolites in Precambrian carbonates: evolutionary mileposts or environmental dipsticks? Annual Review of Earth and Planetary Science 27, 313-58.

Grotzinger, J. P., Watters, W. \& Knoll, A. H. 2000. Diversity, paleoecology, and evolutionary Significance of Thrombolite-Stromatolite-Metazoan Reefs, Terminal
Proterozoic Nama Group, Namibia. Paleobiology 26, 334-59.

HeCKEL, P. H. 1974. Carbonate buildups in the geologic record: a review. In Reefs in Time and Space (ed. L. F. Laporte), pp. 90-154. Society of Economic Paleontologists and Mineralogists, Special Publication no. 18. Tulsa.

Hoffman, P. F. 1969. Proterozoic paleocurrents and depositional history of the east arm fold belt, Great Slave Lake. Canadian Journal of Earth Science 6, 441-62.

Hoffman, P. F. \& Grotzinger, J. P. 1993. Orographic precipitation, erosional unloading, and tectonic style. Geology 21, 195-8.

Horstmann, U. E., Ahrendt, H., Clauer, N. \& PORADA, H. 1990. The metamorphic history of the Damara orogen based on K/Ar data of detrital white micas from the Nama Group, Namibia. Precambrian Research 48, 41-61.

JACKSON, G. D. \& IANNELli, T. R., 1989., Neohelikian reef complexes, Borden Rift Basin, Northwestern Baffin Island. In Reefs. Canada and adjacent areas (eds H. H. J. Geldsetzer, N. P. James and G. E. Tebbutt), pp. 55-63. Canadian Society of Petroleum Geologists, Memoir no. 13. Calgary.

JAMES, N. P. 1983. Reef environment. In Carbonate Depositional Environments (eds P. A. Scholle, D. G. Bebout and C. H. Moore), pp. 345-440. American Association of Petroleum Geologists, Memoir no. 83. Tulsa.

KAH, L. C. \& GRotzinger, J. P. 1992. Early Proterozoic $(1.9 \mathrm{Ga})$ thrombolites of the Rocknest Formation, Northwest Territories, Canada. Palaios 7, 305-15.

Kaufman, A. J., Hayes, J. M., Knoll, A. H. \& Germs, G. J. B. 1991. Isotopic compositions of carbonates and organic carbon from upper Proterozoic successions in Namibia: stratigraphic variation and the effects of diagenesis and metamorphism. Precambrian Research 49, 301-27.

KenNARD, J. M. \& JAMES, N. P. 1986. Thrombolites and stromatolites: Two distinct types of microbial structures. Palaios 1, 492-503.

KNOLL, A. H. 1992. The early evolution of eucaryotes: A geological perspective. Science 256, 622-7.

MARTIN, H. 1965. The Precambrian geology of southwest Africa and Namaqualand. Cape Town: Precambrian Research Unit, University of Cape Town, 159 pp.

Miller, R. M. 1983. The Pan-African Damara orogen of South West Africa/Namibia. In Evolution of the Damara Orogen (ed. R. M. Miller), pp. 431-515. Geological Society of South Africa, Johannesburg.

NARBOnNE, G. M. \& JAMES, N. P. 1996. Mesoproterozoic deep-water reefs from Borden Peninsula, Arctic Canada. Sedimentology 43, 827-48.

PRATT, B. R. \& JAMES, N. P. 1982. Cryptalgal-metazoan bioherms of early Ordovician age in the St. George Group, western Newfoundland. Sedimentology 29, 54369.

Pratt, B. R. \& JAmes, N. P. 1986. The St. George Group (Lower Ordovician) of western Newfoundland: tidal flat island model for carbonate sedimentation in shallow epeiric seas. Sedimentology 33, 313-43.

RIDING, R. \& ZHURAVLEV, A. Y. 1995. Structure and diversity of oldest sponge-microbe reefs: Lower Cambrian, Aldan River, Siberia. Geology 23, 649-52.

SANDBERG, P. 1985. Aragonite cements and their occurrence in ancient limestone. In Carbonate Cements (eds 
N. Schneidermann and P. M. Harris), pp. 33-57. Society of Economic Paleontologists and Mineralogists, Special Publication no. 36.

SAYLOR, B. Z. 2003. Sequence stratigraphy and carbonatesiliciclastic mixing in a terminal Proterozoic foreland basin, Urusis Formation, Nama Group, Namibia. Journal of Sedimentary Research 73, 263-79.

SAYLOR, B. Z. \& GROTZINGER, J. P. 1996. Reconstruction of important Proterozoic-Cambrian boundary exposures through the recognition of thrust deformation in the Nama Group of southern Namibia. Communications of the Geological Survey of Namibia 11, 1-12.

SAYlor, B. Z., Grotzinger, J. P. \& Germs, G. J. B. 1995. Sequence stratigraphy and sedimentology of the Neoproterozoic Kuibis and Schwarzrand Subgroups (Nama Group), Southwest Namibia. Precambrian Research 73, 153-71.

SaYlor, B. Z., Kaufman, A. J., Grotzinger, J. P. \& URBAN, F. 1998. A composite reference section for terminal Proterozoic strata of southern Namibia. Journal of Sedimentary Research 66, 1178-95.

SEPKOSKI, J. J. 1992. Proterozoic-Early Cambrian diversification of metazoans and metaphytes. In The Proterozoic Biosphere (eds J. W. Schopf and C. Klein), pp. 553-61. Cambridge: Cambridge University Press.

SHINN, E. A. 1963. Spur and groove formation on the Florida reef tract. Journal of Sedimentary Petrology 33, 291303.

SNEH, A. \& FRIEDMAN, G. M. 1980. Spur and groove patterns on the reefs of the northern gulfs of the Red Sea. Journal of Sedimentary Petrology 50, 981-6.

Southard, J. B., Lambie, J. M., Federico, D. C., Pile, H. T. \& Weidman, C. R. 1990. Experiments on bed configurations in fine sands under bidi-rectional purely oscillatory flow, and the origin of hummocky crossstratification. Journal of Sedimentary Petrology 60, 117.

Tucker, M. E. \& Wright, V. P. 1990. Carbonate Sedimentology. Oxford: Blackwell Scientific Publications, $482 \mathrm{pp}$.

Tucker, M. E., Calvet, F. \& Hunt, D., 1993. Sequence stratigraphy of carbonate ramps: systems tracts, models and application to the Muschelkalk carbonate platforms of eastern Spain. In Sequence Stratigraphy and Facie Associations (eds H. W. Posamentier, C. P. Summerhayes, B. U. Haq and G. P. Allen), pp. 397-415. International Association of Sedimentologists, Special Publication no. 18. Oxford.

Turner, E. C., James, N. P. \& Narbonne, G. M. 1997. Growth dynamics of Neoproterozoic calcimicrobial reefs, Mackenzie Mountains, northwest Canada. Journal of Sedimentary Petrology 67, 437-50.

Turner, E. C., NARbonNe, G. M. \& JAMEs, N. P. 1993. Neoproterozoic reef microstructures from the Little Dal Group, northwestern Canada. Geology 3, 25962.

Valentine, J. W., Awramik, S. M., Signor, P. W. \& SADLER, P. M. 1991. The biological explosion at the Precambrian-Cambrian boundary. Evolutionary Bio$\log y$ 25, 251-79.

WALter, M. R. \& Heys, G. R. 1984. Links between the rise of the metazoa and the decline of stromatolites. Precambrian Research 29, 149-74.

WILSON, J. L. 1975. Carbonate facies in geologic history. New York: Springer-Verlag, 470 pp.

Wood, R., Grotzinger, J. P. \& Dickson, J. A. D. 2002. Proterozoic modular biomineralized metazoan from the Nama Group, Namibia. Science 296, 2383-6. 